\title{
Modeling profitability for the smallest marine endotherms: auklets foraging within pelagic prey patches
}

\author{
James R. Lovvorn* \\ Department of Zoology, Southern Illinois University, Carbondale, Illinois 62901, USA
}

\begin{abstract}
Auklets (Alcidae) can be very abundant in north-temperate to arctic seas. Their numbers and trophic impacts in a given area depend on their ability to forage profitably as a function of the dispersion, depth, and density of prey patches. Thus, modeling these relationships is important when predicting the auklets' response to environmental change. This paper presents a simulation model of the foraging costs and intake rates of Cassin's auklets Ptychoramphus aleuticus ( 170 g) and least auklets Aethia pusilla ( $80 \mathrm{~g}$ ) once they have located a patch of zooplankton prey. In the model, water temperature and dive depth (max. $20 \mathrm{~m}$ ) have important effects on dive costs, mainly by affecting the duration and magnitude of costs during passive ascent. Within a prey patch, modeled intake rates are limited at relatively low prey densities by pursuit and handling time after a prey item is detected. Because intake rate is limited by capture time and not prey visibility, the model indicates that changes in light conditions over these depths have little direct effect on intake rates of zooplankton prey. However, vertical migration of prey in response to diel light cycles can strongly affect profitability (energy gain minus cost) by altering the depth of dives to prey patches. Because pursuit and handling time limit modeled intake rate, profitability cannot be increased further by finding patches of higher density, but rather by extending time in patches by swimming farther or slower. The model suggests that auklet dispersion should be insensitive to variations in patch density above a threshold that is relatively low compared to the very high densities that can occur. However, auklets may be attracted to higher-density patches because the patches themselves are more visible or predictable, or because other predators-from seabirds to whales - may gather in such patches and increase their visibility.
\end{abstract}

KEY WORDS: Alcidae $\cdot$ Body size scaling $\cdot$ Diving birds $\cdot$ Dive loggers $\cdot$ Energetics models $\cdot$ Krill predators · Visual foraging

\section{INTRODUCTION}

Small auklets weighing 70 to $280 \mathrm{~g}$ can be very abundant in north-temperate, subarctic, and arctic seas. Numbers of only 4 of 6 small auklet species in the marine waters of Alaska are estimated at 13 to 16.5 million (Denlinger 2006), with perhaps 4 million auklets nesting on St. Lawrence Island alone (Gall et al. 2006). Dovekies Alle alle are estimated to number 30 to 60 million breeders in the North Water Polynya region west of Greenland (Karnovsky \& Hunt 2002). The apparent trophic importance of these abundant predators (Schneider \& Hunt 1982, Karnovsky \& Hunt 2002) highlights the need for models that predict the response of auklets to environmental change (Durell et al. 2006, Lovvorn et al. 2009). The abundance and trophic impacts of auklets in a given area depend on their ability to forage profitably as a function of the dispersion, depth, and density of prey patches. To model profitability (energy intake minus cost), one must estimate intake rate at a given prey density and light level, as well as the cost of diving to a prey patch.

Intake rates at varying prey densities and light levels are poorly known for diving birds, having been measured only for little penguins Eudyptula minor and double-crested cormorants Phalacrocorax auritus pur- 
suing small numbers of fish in experimental tanks (Cannell \& Cullen 1998, Enstipp et al. 2007). Intake rates of birds feeding on swarms of zooplankton have not been measured. Lovvorn et al. (2001a) developed a simulation model for short-tailed shearwaters Puffinus tenuirostris feeding on krill (euphausiids) at different densities and light levels, but key parameters were drawn from related literature and have not been verified by direct measurements in wild or captive birds.

Regarding dive costs, bird-borne dataloggers are increasingly critical sources of data for developing and evaluating models, but their application to auklets has been limited by small body size. Such loggers include time-depth recorders (TDRs), accelerometers, and heart rate loggers (Kato et al. 2003, Tremblay et al. 2003, Butler et al. 2004, Watanuki et al. 2006, Harding et al. 2009). At the time of writing this paper, minimum sizes of loggers used in published studies were about $8 \times 16 \times$ $27 \mathrm{~mm}$ and $5 \mathrm{~g}$ for TDRs, $50 \times 15 \mathrm{~mm}$ and $14 \mathrm{~g}$ for cylindrical accelerometer-TDRs (Kato et al. 2003), and $40 \times$ $30 \times 13 \mathrm{~mm}$ and $20 \mathrm{~g}$ for heart rate loggers (Butler et al. 2004). Further miniaturization is expected, and smaller loggers are being employed in ongoing research.

It is difficult to separate effects of extra mass vs. extra drag of loggers on the behavior and energy costs of diving birds. The maximum percentage of body mass to avoid compromising aerial flight is $4 \%$ (Caccamise \& Hedin 1985), and murres with TDRs weighing only 2.4 to $2.7 \%$ of body mass lost 5 to 7 times more mass than controls (Paredes et al. 2005). Thus, all these logger types are currently too large for least auklets Aethia pusilla (LEAU), and accelerometer-TDRs and heart rate loggers are too large for the other small auklets (Fig. 1). In this paper, I collectively refer to parakeet auklets $C y$ clorhynchus psittacula, $\sim 270 \mathrm{~g}$ ), crested auklets Aethia cristatella ( 250 g), Cassin's auklets Ptychoramphus aleuticus (CAAU, $\sim 170 \mathrm{~g}$ ), dovekies (DOVE, $\sim 170 \mathrm{~g}$ ), whiskered auklets Aethia pymaea ( 110 g), and LEAU $(\sim 80 \mathrm{~g})$ as 'small auklets', as opposed to rhinoceros auklets Cerorhinca monocerata (RHAU), which average about $490 \mathrm{~g}$ and $50 \mathrm{~cm}^{2}$ frontal area (including folded wings). A more serious constraint than the mass of externally-mounted loggers is their effect on hydrodynamic drag during swimming. Loggers with frontal (cross-sectional) area $>2 \%$ of the frontal area of the bird can adversely affect body mass, dive patterns, swim costs, and breeding behavior and success (Culik \& Wilson 1991, Paredes et al. 2005, Ropert-Coudert et al. 2007). For the above logger dimensions, the underwater drag of all these loggers probably has appreciable negative effects on all small auklets (Fig. 1). TDRs weighing $5 \mathrm{~g}$ have been deployed on dovekies (3.3\% of body mass in Harding et al. 2009; N. J. Karnovsky, unpubl.), and TDR studies on Cassin's auklets are ongoing (J. Adams, K. H. Elliott, N. J. Karnovsky unpubl.).
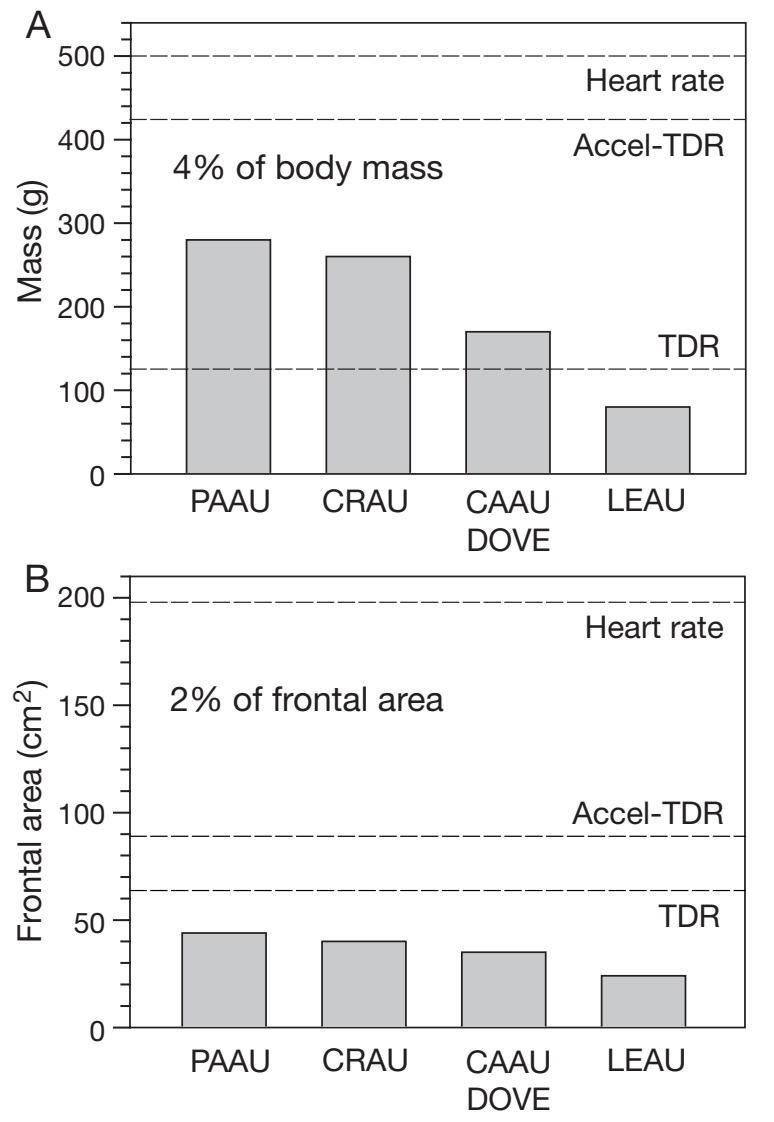

Fig. 1. (A) Mean body mass of auklets (gray bars) relative to minimum body masses (dashed lines) needed to keep logger mass below $4 \%$ of body mass, and (B) mean frontal area of auklets (including folded wings, gray bars) relative to minimum body frontal areas (dashed lines) needed to keep logger frontal area below $2 \%$ of body frontal area for time-depth recorders (TDR), accelerometer-TDRs, and heart rate loggers. Body masses and frontal areas are from Gaston \& Jones (1998) and J. R. Lovvorn (unpubl). PAAU= parakeet auklet, CRAU = crested auklet, CAAU = Cassin's auklet, DOVE = dovekie, LEAU = least auklet

However, despite further miniaturization, data from TDRs for the smaller auklets must be interpreted carefully. At present, limited data require that dive patterns of the smaller auklets (especially LEAU) be inferred by scaling down from larger birds.

Once dive behavior has been described with loggers or other methods, costs must be assigned based on measurements under controlled conditions (e.g. Croll \& McLaren 1993, Richman \& Lovvorn 2008). Dive costs can vary with a range of factors, including swim speed, dive depth, water temperature, and replacement of heat lost to water by heat from digestion or exercising muscles (Lovvorn et al. 1999, Enstipp et al. 2006, Kaseloo \& Lovvorn 2006). Data from heart rate loggers and accelerometers, if related to respirometry for specific behaviors under relevant conditions, can yield valuable insights into costs of different activities in free- 
ranging birds (Butler et al. 2004, Halsey et al. 2009). However, these loggers are still too large for smaller auklets (Fig. 1), leaving respirometry of captive birds as the main approach to estimating costs of different activities in the field. Although metabolic costs of resting in air have been measured for small auklets (Roby \& Ricklefs 1986; Gabrielsen et al. 1991), no values for dive costs of alcids are available except for common murres Uria aalge (COMU) and thick-billed murres U. lomvia (TBMU) diving to a depth of $2 \mathrm{~m}$ (Croll \& McLaren 1993). The latter measurements do not account for major changes in the buoyancy of air volumes over a greater range of depths, or corresponding adjustments of swim speed at depths below $2 \mathrm{~m}$ (Lovvorn et al. 2004). To account for such effects, an alternative approach is to estimate mechanical work against drag and buoyancy, and then to convert mechanical costs to aerobic costs with an aerobic efficiency factor based on experimental measurements (Lovvorn et al. 2004, Lovvorn 2007).

Given the shortage of studies, dive patterns and costs for small auklets must be scaled down from data and models for larger birds. As auklets are the smallest marine endotherms, their relatively high heat loss and high costs of transport may result in high sensitivity to water temperature, dive depth, and intake rate. In this paper, I present a model of dive costs and energy intake rates for 2 auklet species differing in mean body mass: CAAU $(\sim 170 \mathrm{~g})$ and LEAU ( 80 g). Where possible, I examine the extent to which energy costs scale with body mass, and identify critical measurements needed to verify and refine models of energy cost under varying conditions. Although variables key to existing visual foraging models for birds underwater have not been measured, I examine the behavior of one such model and prioritize research needed to provide critical parameters. Most models of foraging by diving endotherms have dealt with searching from the air or underwater for individual prey or small prey patches that yield assumed intake rates, often from the standpoint of optimal use of oxygen stores (Ydenberg \& Clarke 1989, Wilson et al. 1996, Mori 1998, Fauchald 1999, Thompson \& Fedak 2001). In contrast, the model presented here considers foraging within a small-scale prey patch once it has been located (cf. Hamer et al. 2009), and the mechanisms that determine whether foraging dives within that patch would indeed be profitable.

\section{MATERIALS AND METHODS}

Dive costs. Almost all dives by 15 CAAU instrumented in the Santa Barbara Channel, California (J. Adams, unpubl. data), and by 1 CAAU instrumented in British Columbia (Burger \& Powell 1990), were to depths $<20 \mathrm{~m}$; thus, I assumed that no dives by either CAAU or LEAU were deeper than $20 \mathrm{~m}$. To estimate costs of diving, I used the modeling approach of Lovvorn et al. (2004). This approach estimates mechanical work against drag, buoyancy, and inertia of the body and entrained water (added mass) during each swimming stroke at different depths, and then converts mechanical work into aerobic work (chemical substrate requirements) by means of an aerobic efficiency $\eta$ (Lovvorn 2007). For a larger wing-propelled alcid (TBMU) it was previously shown that inertial work is a negligible fraction of the total mechanical work of diving compared to work against drag and buoyancy (Lovvorn et al. 1999, 2004). Moreover, currently available accelerometers are still too large for deployment on small auklets, so there were no data for describing acceleration patterns throughout single strokes. Consequently, inertial work was not included in the model in the present study.

Buoyancy of body tissues was based on body composition. A 167 g CAAU collected in Alaska in September contained (sheared of feathers) $98.0 \mathrm{~g}$ water, $33.8 \mathrm{~g}$ protein, $20.3 \mathrm{~g}$ lipid, and $4.9 \mathrm{~g}$ ash. Six LEAU weighing $80 \pm 12 \mathrm{~g}$ (mean $\pm \mathrm{SD}$ ) collected in Alaska in June-July contained an average $49.3 \pm 7.3 \mathrm{~g}$ water, $22.1 \pm 3.1 \mathrm{~g}$ protein, $4.9 \pm 2.3 \mathrm{~g}$ lipid, and $3.3 \pm 0.6 \mathrm{~g}$ ash. For buoyancies of $-2.302 \mathrm{~N} \mathrm{~kg}^{-1}$ protein, $0.738 \mathrm{~N} \mathrm{~kg}^{-1}$ lipid, and $-6.508 \mathrm{~N} \mathrm{~kg}^{-1}$ ash (Lovvorn et al. 1999), these values yield tissue buoyancies of $-0.095 \mathrm{~N}$ for CAAU and $-0.068 \mathrm{~N}$ for LEAU. Volume of the respiratory system at the water surface after exhalation $\left(V_{\text {resp, } 1}\right)$ was estimated from body mass $\left(M_{\mathrm{b}}, \mathrm{kg}\right)$ by Lasiewski and Calder's (1971) general allometric equation, where $V_{\text {resp }}=0.1608 M_{\mathrm{b}}^{0.91}$ (for details, see Lovvorn et al. 1999), yielding $0.032 \mathrm{l}$ for CAAU weighing $0.170 \mathrm{~kg}$, and $0.016 \mathrm{l}$ for LEAU weighing $0.080 \mathrm{~kg}$. Volume of air in the plumage at the water surface was estimated to be $0.33 \mathrm{l} \mathrm{kg}^{-1}$ based on measurements by Wilson et al. (1992), yielding 0.0561 for CAAU and 0.0261 for LEAU (note that the equation for much larger birds in Fig. 4 of Lovvorn \& Jones [1991] does not give reasonable predictions for much smaller auklets). Although there may be some nonlinearity in the scaling of plumage air volume with body mass, the scaling of surface area with body mass for auklets in this size range is essentially linear (Fig. 2; surface area measured on frozen birds by covering them with plastic film and tape, and measuring the area of the removed plastic form, see Lovvorn et al. 1991). This pattern suggests that a constant linear relationship of air volume with body mass $\left(0.33 \mathrm{l} \mathrm{kg}^{-1}\right)$ is within measurement error over this small mass range. As depth below the water surface increases, air volume decreases by a factor of $10 /(n+$ $10)$, where $n$ is depth in meters. The buoyancy of air 
spaces at different depths was calculated as $9.79 \mathrm{~N} \mathrm{l}^{-1}$ of air (Lovvorn et al. 1999). Estimated total buoyancies (including both body tissues and air spaces) of CAAU were higher and declined more rapidly over the upper $20 \mathrm{~m}$ of the water column than for LEAU (Fig. 3).

Mean speeds and angles (relative to horizontal) of swimming during descent were based on micrologger measurements for 4 alcids-TBMU, COMU, razorbill Alca torda (RAZO), and RHAU-and little penguins

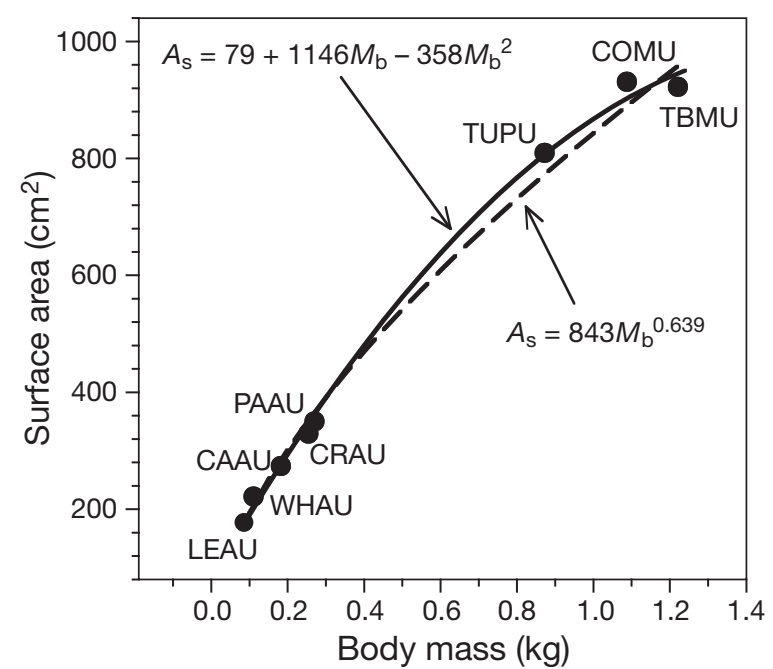

Fig. 2. Total body surface area $\left(A_{\mathrm{s}}\right)$ versus body mass $\left(M_{\mathrm{b}}\right)$ for least auklet (LEAU, $\mathrm{n}=6$ ), whiskered auklet (WHAU, $\mathrm{n}=5$ ), Cassin's auklet (CAAU, $n=2$ ), crested auklet (CRAU, $n=9$ ), parakeet auklet (PAAU, $\mathrm{n}=8$ ), tufted puffin Fratercula cirrhata (TUPU, $\mathrm{n}=2)$, common murre (COMU, $\mathrm{n}=5)$, and thick-billed murre (TBMU, $\mathrm{n}=4$ ). For both quadratic and allometric equations, $\mathrm{r}^{2}>0.99, \mathrm{p}<0.001$

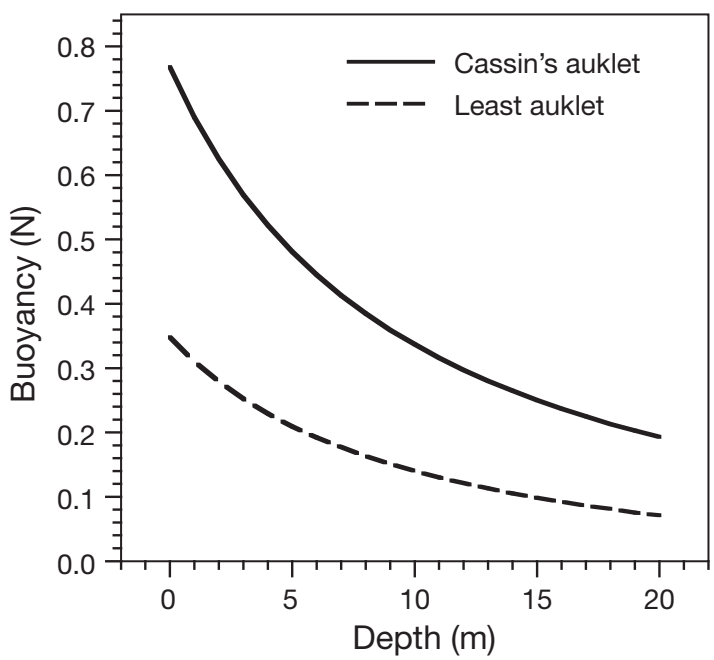

Fig. 3. Ptychoramphus aleuticus and Aethia pusilla. Estimated change in buoyancy with water depth for Cassin's auklet (CAAU, $0.17 \mathrm{~kg}$ ) and least auklet (LEAU, $0.08 \mathrm{~kg}$ )
(LIPE) (Watanuki et al. 2006). Extrapolating from regression of swim speed vs. body mass yielded estimated mean speeds during descent of $0.88 \mathrm{~m} \mathrm{~s}^{-1}$ for CAAU and $0.80 \mathrm{~m} \mathrm{~s}^{-1}$ for LEAU (Fig. 4A). Descent angle (relative to horizontal) for both CAAU and LEAU was assumed to be the same as the mean for RHAU $(0.57 \mathrm{~kg})$ diving to about $20 \mathrm{~m}$ depth: $-47^{\circ}$ (Fig. 5 in Watanuki et al. 2006). Hydrodynamic drag $D(\mathrm{~N})$ was based on tow-tank measurements at different speeds $U\left(\mathrm{~m} \mathrm{~s}^{-1}\right)$ for frozen birds (Lovvorn et al. 2001b). For CAAU,

$$
D=-0.206+1.28 U-0.267 U^{2}+0.0914 U^{3}
$$
and for LEAU,

$$
D=0.174+0.387 U-0.0126 U^{2}+0.0154 U^{4}
$$

(Fig. 5). Drag was multiplied by the actual swim distance per meter of vertical descent at the given descent angle to calculate work against drag $(\mathrm{J})$ per meter of vertical descent. Work against buoyancy (Fig. 3) and drag (Fig. 5) were summed over $1 \mathrm{~m}$ depth increments, and cumulative values were regressed against

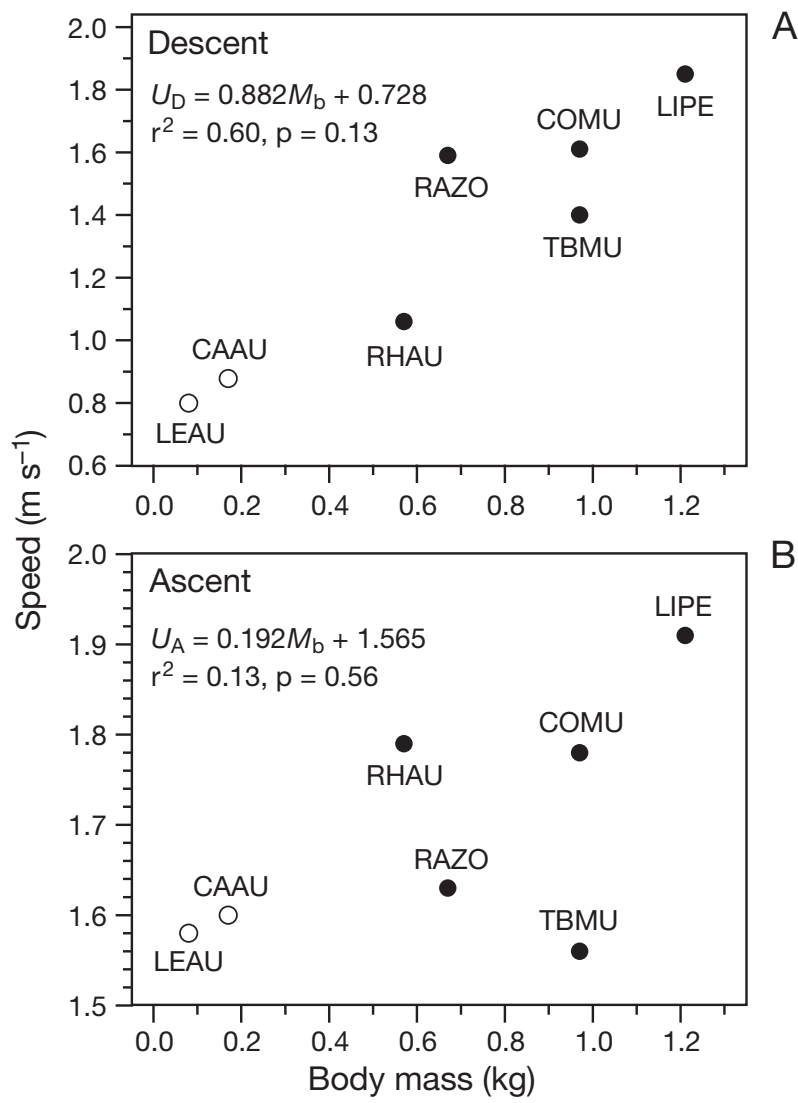

Fig. 4. Mean speeds $(U)$ versus body mass $\left(M_{\mathrm{b}}\right)$ during $(\mathrm{A})$ descent $\left(U_{\mathrm{D}}\right)$ and $(\mathrm{B})$ passive ascent $\left(U_{\mathrm{A}}\right)$ in little penguin (LIPE), common murre (COMU), thick-billed murre (TBMU), razorbill (RAZO), and rhinoceros auklet (RHAU) measured with time-depth recorders by Watanuki et al. (2006) (๑), and estimated for Cassin's auklet (CAAU) and least auklet (LEAU) from linear regressions fit to those measured points $(\mathrm{O})$ 


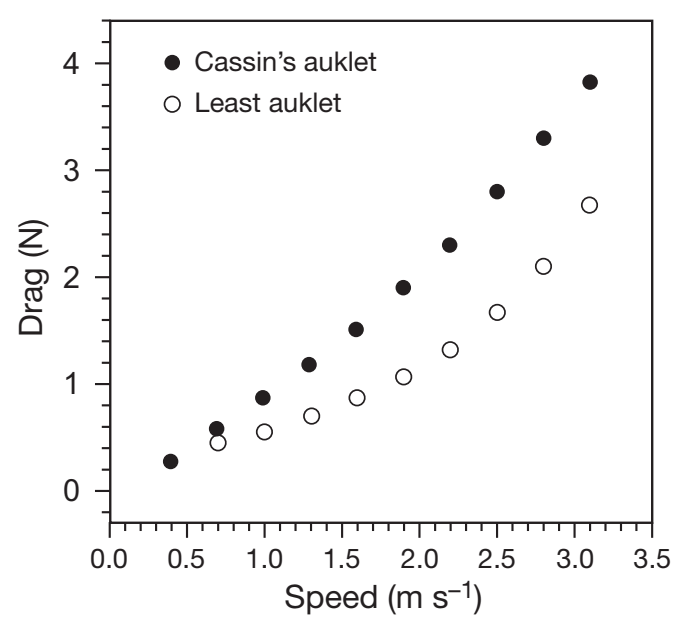

Fig. 5. Ptychoramphus aleuticus and Aethia pusilla. Tow-tank measurements of hydrodynamic drag at a range of speeds for frozen specimens of Cassin's auklet $(0.17 \mathrm{~kg})$ and least auklet $(0.08 \mathrm{~kg})$ (data from Lovvorn et al. 2001b)

depth $z(\mathrm{~m})$ to yield estimates of the mechanical work of descent to different depths $\left(W_{\mathrm{z}}, \mathrm{J}\right)$. For CAAU,

$$
W_{\mathrm{z}}=1.250+1.419 z
$$

and for LEAU,

$$
W_{\mathrm{z}}=0.603+0.810 z
$$

(for both equations, $\mathrm{r}^{2}>0.99, \mathrm{p}<0.001$ ).

No field measurements of the speeds of horizontal swimming at the bottom of dives are available for diving birds that also fly in air. As the volume and buoyancy of air spaces declined with increasing depth during descent, TBMU increased their speed and associated drag to maintain relatively constant work per stroke (Lovvorn et al. 2004). This strategy was thought to maximize muscle efficiency. When work against buoyancy is at its lowest for the dive during horizontal swimming at the bottom, birds may increase their speed to maintain work rates with high muscle efficiency, but may also slow down to facilitate capture of prey. Lacking relevant data, we assumed that small auklets would maintain the same speed during horizontal swimming at the bottom of dives as during descent: $0.88 \mathrm{~m} \mathrm{~s}^{-1}$ for CAAU and $0.80 \mathrm{~m} \mathrm{~s}^{-1}$ for LEAU (see above text). Mechanical work against drag at these speeds was estimated by multiplying results of Eqs. (1) or (2) by the bottom (horizontal) swim distance. To estimate work against the buoyant force $B(\mathrm{~N})$ to maintain constant depth during horizontal swimming, we reasoned that an auklet had to progress downward the distance $X(\mathrm{~m})$ it would otherwise float upward during a given time increment $t(\mathrm{~s})$ :

$$
X=U_{0} t+1 / 2\left(B / M_{\mathrm{v}}\right) t^{2}
$$

where $U_{0}$ is initial vertical velocity (equal to zero), $M_{\mathrm{v}}(\mathrm{kg})$ is virtual mass (body mass plus added mass of entrained water), and $B / M_{\mathrm{v}}$ is the acceleration imparted by the buoyant force (Lovvorn et al. 1991). Based on the maximum circumference and length of frozen auklets, we used an added mass coefficient of 0.075 (the fractional increase in body mass due to entrained water to yield $M_{\mathrm{v}}$, Kochin et al. 1964). This work against buoyancy $W_{\mathrm{B}}$ during time $t$ was then calculated as $W_{\mathrm{B}}=B \times X$, and added to work against drag during horizontal swimming at swim distance increments of $0.3 \mathrm{~m}$.

For 4 alcid species equipped with logging TDRaccelerometers (TBMU, COMU, RAZO, RHAU), stroking ceased during ascent at depths shallower than $20 \mathrm{~m}$ (Watanuki et al. 2006). Accordingly, we assumed passive ascent above that depth; however, strokes to begin ascent may increase the subsequent passive speed over that imparted by buoyancy alone. Thus, we estimated ascent swim speeds for the small auklets from a rather variable regression of ascent swim speed vs. body mass as measured for the larger alcids (Fig. 4B). Ascent angle (relative to horizontal) was assumed to be the same as for RHAU $\left(47^{\circ}\right)$ in the same study (Fig. 5 in Watanuki et al. 2006).

Mechanical costs of descent were converted to aerobic costs (chemical substrate requirements) by an aerobic efficiency $(\eta=$ mechanical power output $\div$ aerobic power input) of 0.14 , as measured for lesser scaup ducks Aythya affinis diving to a depth of $2 \mathrm{~m}$ in a tank at $8^{\circ} \mathrm{C}$ (Kaseloo \& Lovvorn 2005). Aerobic efficiency subsumes thermoregulation costs, which may increase nonlinearly as body mass decreases over large ranges. However, nonlinearity in heat loss with mass appears to depend strongly on nonlinear increase in surface area as body mass decreases, and surface area appears to scale almost linearly with body mass over the mass range of small auklets (Fig. 2). Moreover, resting metabolic rate (RMR) in air at thermoneutral temperature also scales linearly over the range of body mass of alcids (Fig. 6). Lacking better data, we assumed that $\eta$ was the same for CAAU and LEAU at the same temperatures. For RMR (W) during passive ascent at different water temperatures, we used a relation for TBMU weighing an average $0.803 \mathrm{~kg}$ floating on water $(\mathrm{w})$ at temperatures $T_{\mathrm{w}}$ from 0 to $21^{\circ} \mathrm{C}: \mathrm{RMR}_{\mathrm{w}}=M_{\mathrm{b}}(20.99-$ $0.77 T_{\mathrm{w}}$ ) (Croll \& McLaren 1993). Using this equation derived from much larger murres again assumes linear increase of heat loss with increasing body mass, reflecting the linear scaling of RMR in air at thermoneutral temperatures (Fig. 6) and of surface area over which heat is lost (Fig. 2).

Energy intake rates. Energy intake rates were estimated as a function of prey density in patches (no. $\mathrm{m}^{-3}$ ) and availability of light for foraging at a given depth, based on a model for underwater visual foraging (Lovvorn et al. 2001a). Profiles of light in visible 


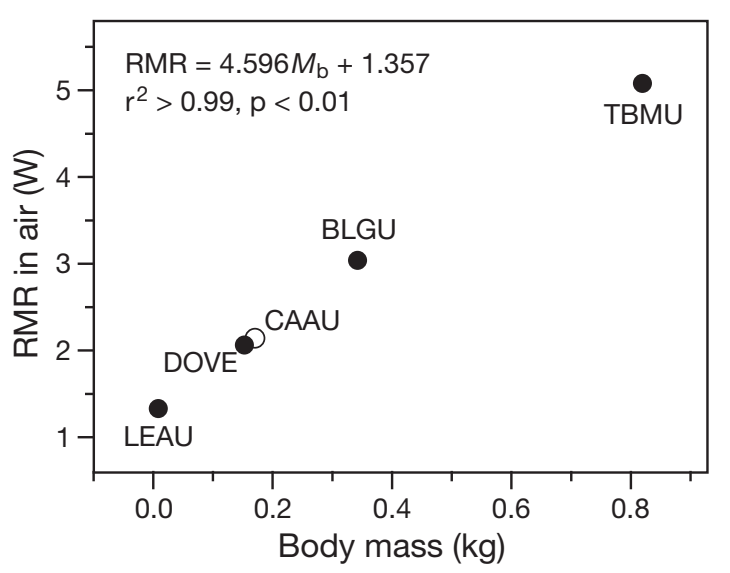

Fig. 6. Mean resting metabolic rate (RMR) in air at thermoneutral temperature relative to body mass $\left(M_{\mathrm{b}}\right)$ of thick-billed murre (TBMU) and black guillemot Cepphus grylle (BLGU) (Gabrielsen et al. 1988), dovekie (DOVE) (Gabrielsen et al. 1991), and least auklet (LEAU) (Roby \& Ricklefs 1986) (•), and estimated for Cassin's auklet (CAAU) from a linear regression fit to those measured points $(O)$

wavelengths (scalar PAR, photosynthetically active radiation, $\left.\mu \mathrm{mol} \mathrm{m} \mathrm{m}^{-2} \mathrm{~s}^{-1}\right)$ and of beam attenuation $\left(\mathrm{m}^{-1}\right)$ were taken from Monterey Bay, California at 8:26 pm on 8 August 2002 by staff of the Monterey Bay Aquarium Research Institute (Fig. 7). During this time of day, CAAU would be feeding on krill (often Thysanoessa spinifera) that had migrated vertically toward the surface at dusk (Fiedler et al. 1998, Adams et al. 2004a). To compare CAAU and LEAU under similar conditions, we used the same light profile. LEAU would experience quite similar profiles of PAR during summer in the southeast Bering Sea, although associated profiles of beam attenuation were so variable as to defy generalization (see Fig. 3 in Lovvorn et al. 2001a).

A detailed explanation of underwater light and vision, and of the visual foraging algorithm used here, is found in Lovvorn et al. (2001a). The main equation used is:

$$
\left.r^{2}=\left[R_{\max } /\left(k_{\mathrm{s}}+R_{\mathrm{z}}\right)\right] R_{\mathrm{z}} \exp \left(-C_{\mathrm{z}} r\right)\right]\left|C_{\mathrm{i}}\right| A_{\mathrm{p}} \Delta S_{\mathrm{e}}^{-1}
$$

where $r=$ visual range $(\mathrm{m}), R_{\max }=$ maximum retinal irradiance that can be processed $\left(\mu \mathrm{mol} \mathrm{m}{ }^{-2} \mathrm{~s}^{-1}\right), k_{\mathrm{s}}=$ saturation parameter for the response of the retina to light, $R_{\mathrm{z}}=$ scalar PAR at depth $z(\mathrm{~m})$ below the water surface $\left(\mu \mathrm{mol} \mathrm{m} \mathrm{m}^{-2} \mathrm{~s}^{-1}\right), C_{\mathrm{z}}=$ beam attenuation coefficient at depth $z\left(\mathrm{~m}^{-1}\right), C_{\mathrm{i}}=$ inherent contrast of prey, $A_{\mathrm{p}}$ $=$ plan area of prey tangent to the line of vision $\left(\mathrm{m}^{2}\right)$, and $\Delta S_{\mathrm{e}}=$ eye sensitivity threshold for detecting change in the rate of photons striking the retina $(\mu \mathrm{mol}$ $\left.\mathrm{m}^{-2} \mathrm{~s}^{-1}\right)$. This equation is solved iteratively for the values of PAR $\left(R_{\mathrm{z}}\right)$ and beam attenuation coefficient $\left(c_{\mathrm{z}}\right)$ at a given depth $z$. The bite-feeding (as opposed to filter-
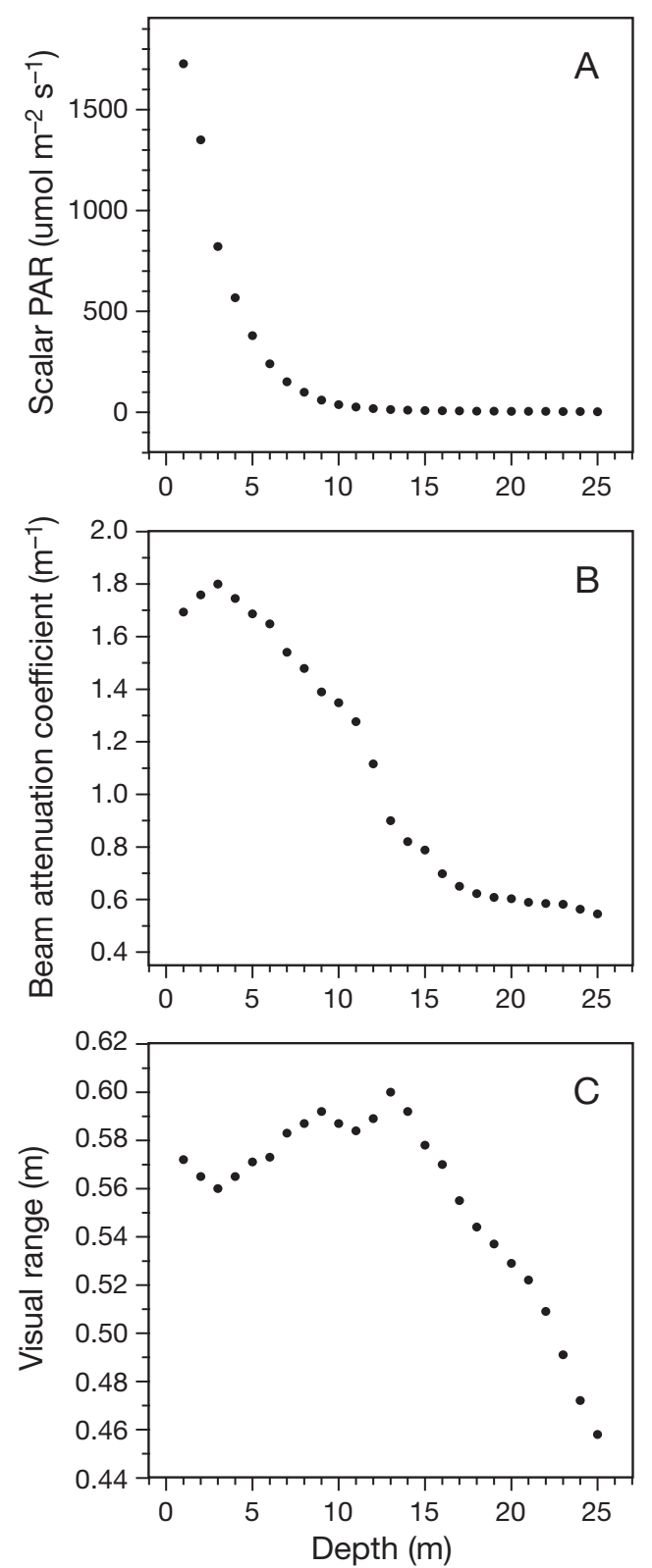

Fig. 7. (A) Scalar PAR and (B) beam attenuation versus water depth in central Monterey Bay, California, USA at 8:26 pm on 8 August 2002, and (C) model estimates of the visual range for detection of adult krill prey Thysanoessa spp. by an avian predator foraging underwater

feeding) intake rate $I_{\mathrm{b}}$ (no. of prey $\mathrm{s}^{-1}$ ) is then calculated as:

$$
I_{b}=\frac{F_{m} P_{C} C_{\mathrm{ph}}^{-1} N}{\left[C_{\mathrm{ph}} \pi(r \sin \theta)^{2} U\right]^{-1}+N}
$$

where $F_{\mathrm{m}}=$ motion detectability factor, $P_{\mathrm{c}}=$ capture probability for prey that are detected, $C_{\mathrm{ph}}=$ capture time (pursuit and handling time after detection) per prey item (s), $N=$ number of prey $\mathrm{m}^{-3}, \theta=$ visual field angle (degrees), and $U=$ swim speed of the predator $\left(\mathrm{m} \mathrm{s}^{-1}\right)$. 
Intake rates are for birds within a prey patch of uniform density. Prey density can vary spatially within swarms (O'Brien 1988), but such variations are typically highly dynamic over periods of seconds and would be difficult to measure and account for. Note that this model is for foraging within prey patches, and does not include searching for such patches from the air or underwater.

Although CAAU eat a variety of prey including copepods, their diet is often dominated by krill (Vermeer 1984, Adams et al. 2004a, Abraham \& Sydeman 2006). For simulations in this paper, I assumed that CAAU were eating entirely adult krill (euphausiids) of the genus Thysanoessa. With mean energy content of $23.0 \mathrm{~kJ} \mathrm{~g}^{1}$ dry mass (Nishiyama 1974), Thysanoessa spp. which are 20 to $25 \mathrm{~mm}$ long and weigh about $9 \mathrm{mg}$ would contain $207 \mathrm{~J}$ per individual, and have a plan area of about $6.7 \times 10^{-5} \mathrm{~m}^{2}$ (see Lovvorn et al. 2001a). I assumed an assimilation efficiency for krill of $68 \%$ (Jackson 1986, Kirkwood \& Robertson 1997). LEAU breeding in the Bering Sea eat mainly copepods of the genus Neocalanus, mostly $N$. flemingeri or $N$. plumchrus, which are difficult to distinguish in diet samples (Roby 1991, Gall et al. 2006). Adults of these copepod species are about $5 \mathrm{~mm}$ long (Hunt \& Harrison 1990), 20-25\% the length of adult Thysanoessa spp. The plan area of adult $N$. plumchrus or $N$. flemingeri $\left(4.42 \times 10^{-6} \mathrm{~m}^{2}\right)$ was determined by weighing paper cut-outs of life-sized photocopied images, and comparing the mass of cut-outs to that of the same paper of known area. Based on content of protein $(0.13 \mathrm{mg})$ and total lipid (0.60 mg) in July (Campbell et al. 2004), and energy equivalents of $18.0 \mathrm{~kJ} \mathrm{~g}^{-1}$ protein and $39.5 \mathrm{~kJ} \mathrm{~g}^{-1}$ lipid (Roby 1991), the energy content of individual $N$. plumchrus or $N$. flemingeri is about $26 \mathrm{~J}$. The latter value is higher than that of $15 \mathrm{~J}$ calculated from the fractional content of protein, lipid, carbohydrate, and chitin in N. plumchrus during summer reported by Ikeda (1972). Using the value of $26 \mathrm{~J}$ and assuming about $96 \%$ digestibility of protein and lipid in copepods (cf. Roby et al. 1986) yields $25 \mathrm{~J}$ per individual copepod.

Uncertainty analyses. I performed uncertainty analyses of the effects of varying selected parameters on profit per dive. In uncertainty analyses, the apparent importance of a variable can depend on the magnitude of the range over which it is varied. If the range is unrealistically large, the variable will appear to have greater influence on the dependent variable than it should. Thus, an attempt was made to select parameter ranges that reasonably might be observed, or that have been observed for the same or similar species (Table 1, see references in previous 2 sections).

For uncertainty analyses, the value of each parameter for a given dive was randomly chosen from a uniform distribution over the ranges listed in Table 1.
Table 1. Ptychoramphus aleuticus. Parameter values and ranges for uncertainty analyses of factors affecting profit per dive ( $\mathrm{J}$ ) by Cassin's auklets. $\eta=$ mechanical power output/ aerobic power input

\begin{tabular}{|lcc|}
\hline Parameter & Default & Range \\
\hline Aerobic efficiency for diving, $\eta$ & 0.14 & $0.10-0.23$ \\
Ascent angle $\left({ }^{\circ}\right)$ & 47 & $20-60$ \\
Bottom swim distance $(\mathrm{m})$ & 3 & $1-5$ \\
Bottom swim speed $\left(\mathrm{m} \mathrm{s}^{-1}\right)$ & 0.88 & $0.7-1.0$ \\
Capture probability, $P_{\mathrm{c}}$ & 0.8 & $0.6-0.9$ \\
Capture time for pursuit and handling & 1.6 & $1.0-2.0$ \\
after detection, $C_{\mathrm{ph}}(\mathrm{s}$ prey & -1 \\
Energy per prey $(\mathrm{J})$ & 207 & $\pm 20 \%$ \\
Prey density within a patch $\left(\mathrm{no}^{-1} \mathrm{~m}^{-3}\right)$ & 150 & $10-200$ \\
Water temperature $\left({ }^{\circ} \mathrm{C}\right)$ & 10 & $0-15$ \\
\hline
\end{tabular}

After simulation of 300 dives, all variables were ranked and the dependent variable (total profit per dive) was regressed against the independent variables (randomly chosen parameter values) for each dive. Relative partial sums of squares (RPSS) for ranked data indicated the proportion of variance in profit per dive explained by variation of individual parameters, with effects of the other parameters statistically removed. I also report partial coefficients of determination (partial $\mathrm{r}^{2}$ ), because parameters can show high correlation but account for small residual variances as indicated by RPSS. Together, these analyses indicate how much changes in the value of a parameter could affect the dependent variable (partial $\mathrm{r}^{2}$ ), and where research effort to decrease the error in a parameter would improve the reliability of predictions (RPSS).

\section{RESULTS}

\section{Aerobic costs of diving}

For both Cassin's auklet (CAAU) and least auklet (LEAU), model estimates of the aerobic costs of descent and ascent increased linearly with increasing dive depth (Fig. 8). Work of horizontal swimming at the bottom of dives decreased nonlinearly with increasing depth as air spaces in the respiratory system and plumage were compressed by greater hydrostatic pressure, thereby reducing work against buoyancy (Fig. 3). Although absolute costs of descent and bottom swimming were higher for larger CAAU, costs per kg were greater for LEAU. Because both ascent speed and RMR in water at different temperatures during ascent were estimated linearly from body mass, costs per kg during ascent were the same for both species. Note that based on the current model and parameters, total costs of passive ascent were somewhat higher than 

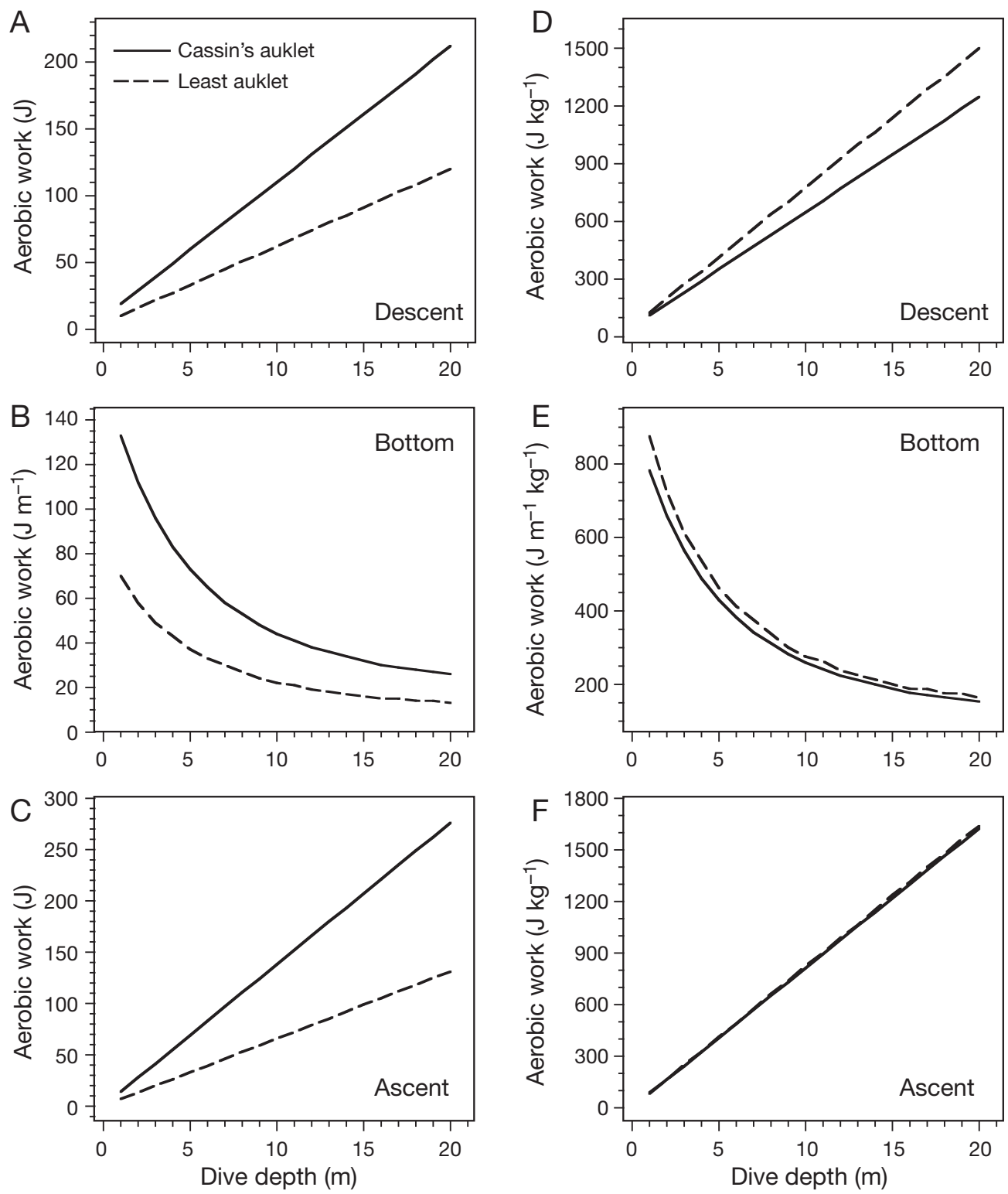

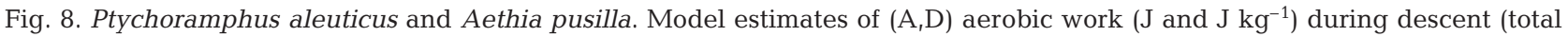
cost), $(\mathrm{B}, \mathrm{E})$ horizontal swimming at the bottom of dives (cost $\mathrm{m}^{-1}$ swum), and $(\mathrm{C}, \mathrm{F})$ ascent (total cost) for dives to a range of depths at $10^{\circ} \mathrm{C}$ by Cassin's auklet $(0.17 \mathrm{~kg})$ and least auklet $(0.08 \mathrm{~kg})$

total costs of powered descent (Fig. 8). Costs per second of descent were in fact greater than those of ascent, but were applied over the much shorter period required to reach the bottom at the higher speed of descent.

\section{Effects of capture probability, capture time, and light level on intake rate}

After CAAU have visually detected a krill prey, both the probability of capturing that prey $\left(P_{\mathrm{C}}\right)$ and the time required for pursuit and handling after de- tection (capture time, $C_{\mathrm{ph}}$ ) had strong effects on intake rates (Fig. 9). Changes in light conditions as depth increased had almost no effect on intake rate to depths of $20 \mathrm{~m}$ (Fig. 9C), because even if the birds could see more prey, they could not handle prey at a faster rate than were already detected at lower light levels. Regardless of $P_{\mathrm{c}}, C_{\mathrm{ph}}$ or light levels, intake rate increased rapidly with increasing prey density only to $\sim 50 \mathrm{krill} \mathrm{m}^{-3}$, above which there was little change (Fig. 9). The same model parameterized for LEAU yielded similar responses to changes in capture time and density of copepod prey (Fig. 10). Because of higher mass-specific costs of diving 
(Fig. 8) and lower energy per prey for LEAU, lower capture times $\left(C_{\mathrm{ph}}\right)$ and thus higher intake of prey $\mathrm{s}^{-1}$ were needed for LEAU eating copepods than for CAAU eating krill to yield reasonable profitability patterns (see next section).
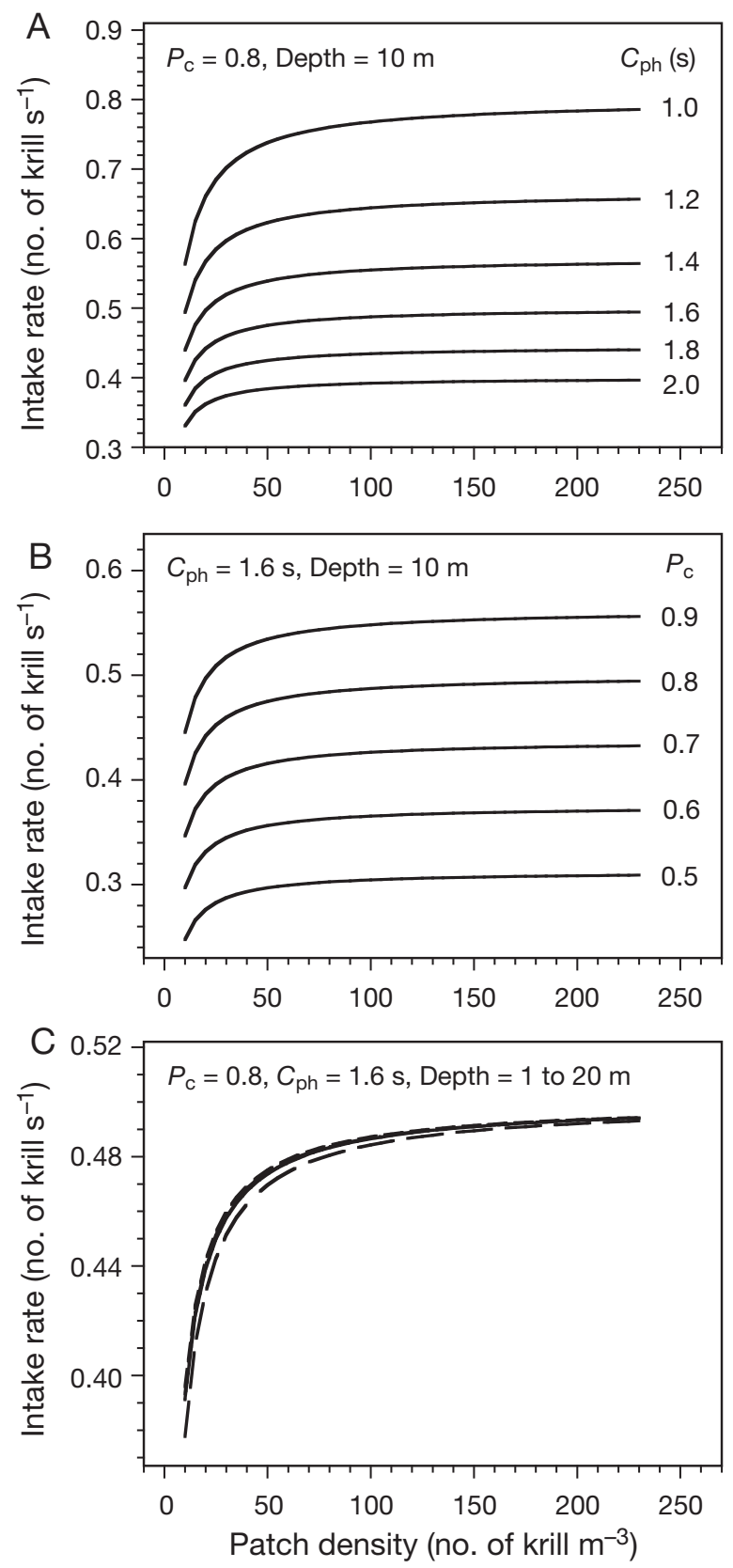

Fig. 9. Ptychoramphus aleuticus. Model estimates of the number of adult krill Thysanoessa spp. ingested per second by a Cassin's auklet foraging within patches of krill over a range of homogenous densities with (A) $P_{\mathrm{c}}$ (probability of capturing a prey item once it is detected) $=0.8$, depth $=10 \mathrm{~m}$, and $C_{\mathrm{ph}}$ (time required for pursuit and handling after detection) varied from 1.0 to $2.0 \mathrm{~s}$, (B) $C_{\mathrm{ph}}=1.6 \mathrm{~s}$, depth $=10 \mathrm{~m}$, and $P_{\mathrm{c}}$ varied from 0.5 to 0.9 , and (C) $P_{\mathrm{c}}=0.8, C_{\mathrm{ph}}=1.6 \mathrm{~s}$, and depth varied from 1 to $20 \mathrm{~m}$ at $5 \mathrm{~m}$ increments

\section{Effects of depth, bottom swim speed, and swim distance}

In the model for CAAU, total profit per dive (energy intake minus cost) decreased with increasing dive depth because of increasing dive costs (Fig. 11). For a constant swim distance of $3 \mathrm{~m}$ within a patch (Fig. 11A-C), energy balance for dives to $8 \mathrm{~m}$ depth was positive at all swim speeds $<1.35 \mathrm{~m} \mathrm{~s}^{-1}$. However, as depth and dive cost increased, maintaining positive energy balance required slowing swim speed to $<0.85 \mathrm{~m} \mathrm{~s}^{-1}$ at $14 \mathrm{~m} \mathrm{depth}$, and to $<0.6 \mathrm{~m} \mathrm{~s}^{-1}$ at $20 \mathrm{~m}$ depth. For a constant bottom swim speed of $0.88 \mathrm{~m} \mathrm{~s}^{-1}$ (Fig. 11D-F), dives were profitable only for bottom swim distances $>1.8 \mathrm{~m}$ at $8 \mathrm{~m}$ depth, $>3.1 \mathrm{~m}$ at $14 \mathrm{~m}$ depth, and $>4.4 \mathrm{~m}$ at $20 \mathrm{~m}$ depth. Thus, as dive costs increase with increasing depth, profitable foraging requires staying in patches longer by either slowing down or swimming farther.

LEAU showed analogous patterns of decreasing total profit as dive costs increased at greater depths (Fig. 12). Maintaining positive energy balance required swimming $>3.2 \mathrm{~m}$ in a patch at $4 \mathrm{~m}$ depth, $>6.4 \mathrm{~m}$ at $8 \mathrm{~m}$ depth, and $>9.1 \mathrm{~m}$ at $12 \mathrm{~m}$ depth. Given these swim distances, this model formulation suggests that it might be difficult for LEAU (body mass only $\sim 80 \mathrm{~g}$ ) to stay in a prey patch long enough to feed profitably at depths $>10 \mathrm{~m}$.

\section{Effects of water temperature}

According to estimates used in this model, water temperature had important effects on total dive profit at

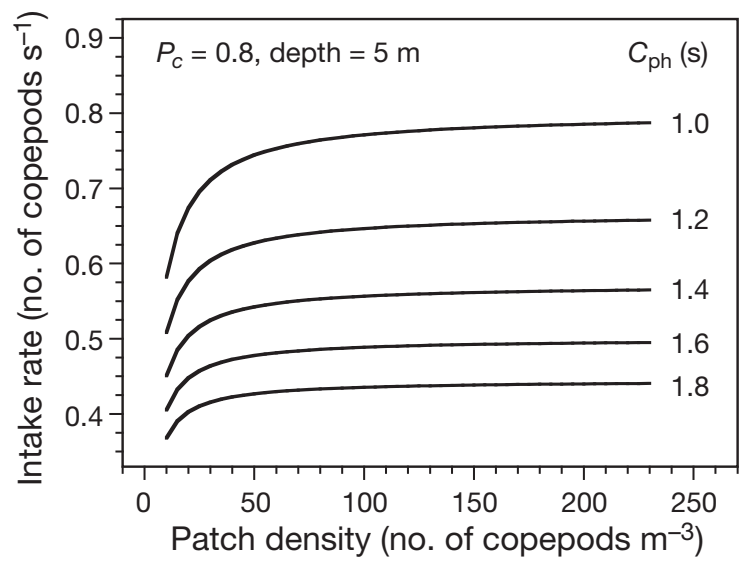

Fig. 10. Aethia pusilla. Model estimates of the number of adult copepods Neocalanus plumchrus or N. flemingeri ingested per second by a least auklet foraging within patches of copepods over a range of homogenous densities, $P_{\mathrm{c}}$ (probability of capturing a prey item after it is detected) $=0.8$, depth $=$ $5 \mathrm{~m}$, and $C_{\mathrm{ph}}$ (time required for pursuit and handling after detection) varied from 1.0 to $1.8 \mathrm{~s}$ 

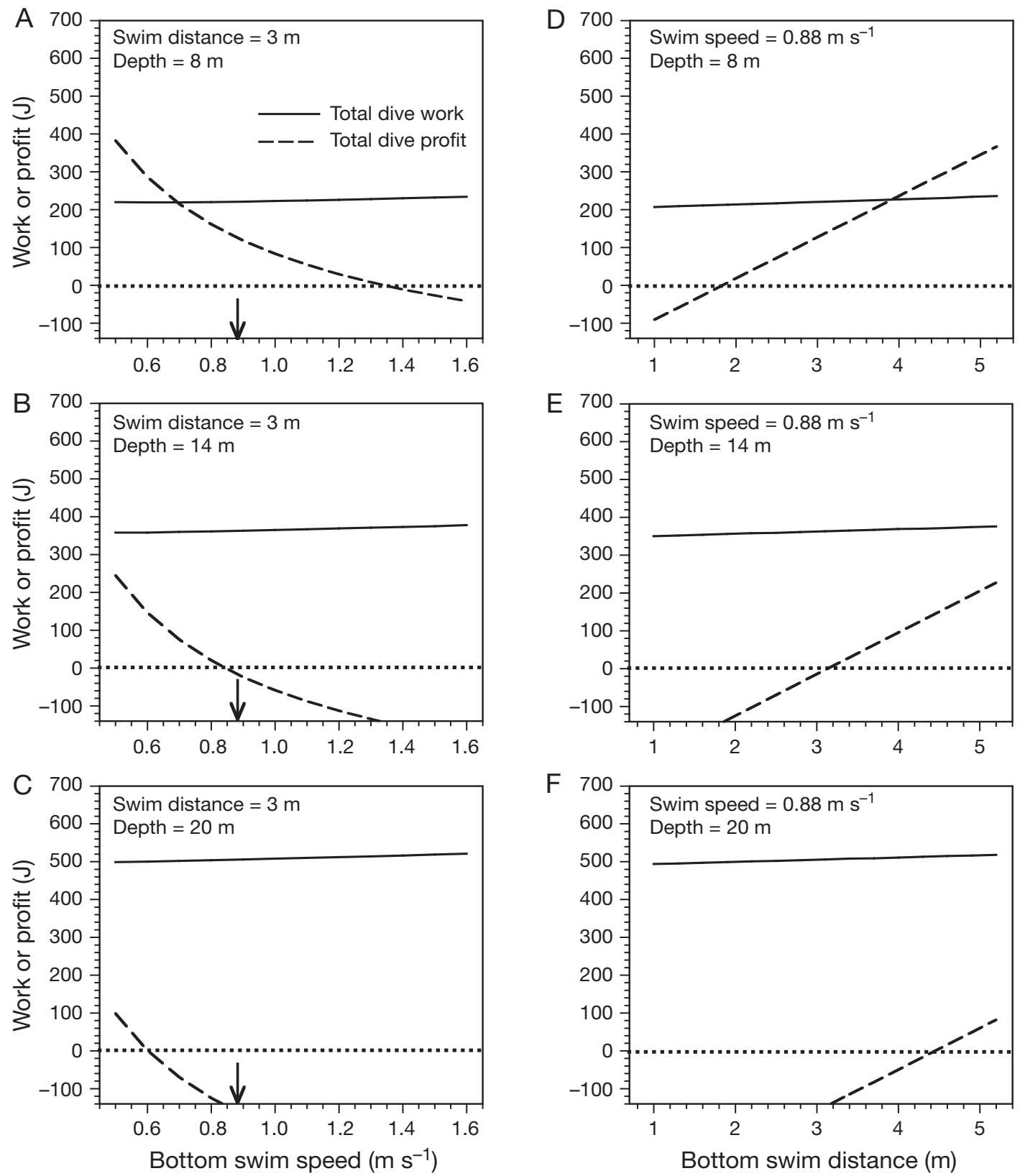

Fig. 11. Ptychoramphus aleuticus. Model estimates of the aerobic work of horizontal swimming at the bottom of dives and total profit for dives as functions of dive depth, speed of bottom swimming, and distance of bottom swimming by Cassin's auklets feeding within patches of adult krill Thysanoessa spp. with homogeneous density $=150 \mathrm{krill} \mathrm{m}^{-3}$, capture probability $\left(P_{\mathrm{c}}\right)=0.8$, and capture time (for pursuit and handling after detection, $C_{\mathrm{ph}}$ ) $=1.6 \mathrm{~s}$. Arrow shows the mean bottom swim speed assumed for Cassin's auklets $\left(0.88 \mathrm{~m} \mathrm{~s}^{-1}\right)$

given depths and bottom swim distances (Fig. 13). These patterns are mainly a function of RMR during ascent, which was extrapolated as a linear function of body mass from data on TBMU floating on water at temperatures from 0 to $21^{\circ} \mathrm{C}$ (Croll \& McLaren 1993, see Materials and Methods). CAAU swimming $3 \mathrm{~m}$ at the bottom of dives within a prey patch could feed profitably at dive depths up to $16 \mathrm{~m}$ at $15^{\circ} \mathrm{C}$, but only at depths $<10 \mathrm{~m}$ at $0^{\circ} \mathrm{C}$. LEAU swimming $6 \mathrm{~m}$ at the bottom of dives could feed profitably at depths up to $9.5 \mathrm{~m}$ at $15^{\circ} \mathrm{C}$, but only at depths $<6 \mathrm{~m}$ at $0^{\circ} \mathrm{C}$. At a given temperature, either species could increase the depth of profitable foraging by swimming slower or farther to extend their time within a patch. However, for LEAU, in particular, oxygen stores will impose a limit on how far they can swim at the bottom of dives (Fig. 12), so low temperature (and proportionally greater heat loss in the smaller LEAU) may place important constraints on dive depths. 

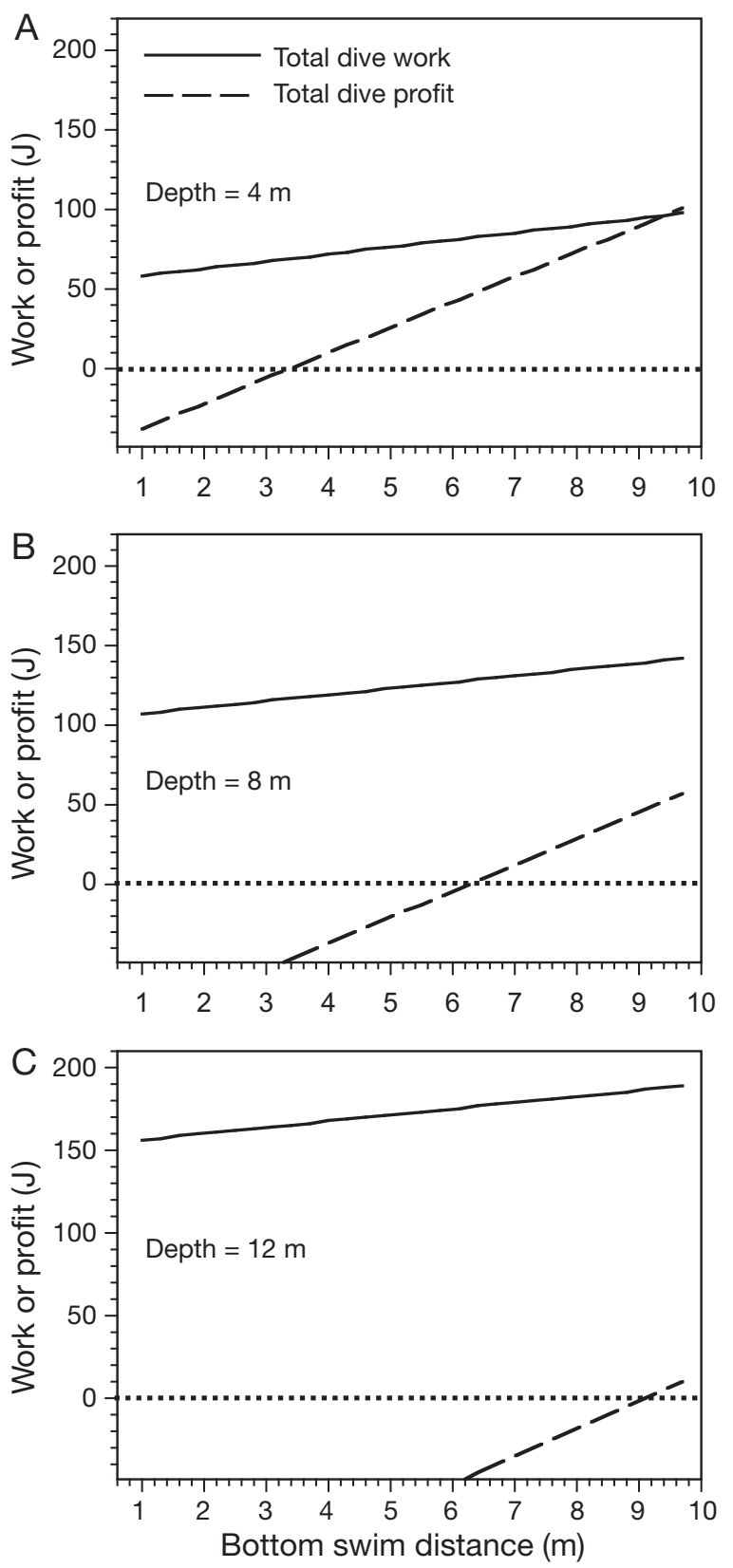

Fig. 12. Aethia pusilla. Model estimates of the aerobic work of horizontal swimming at the bottom of dives and total profit for dives as functions of dive depth and bottom swim distance by least auklets feeding within patches of adult copepods Neocalanus plumchrus or $N$. flemingeri with homogeneous density $=150$ copepods $\mathrm{m}^{-3}$, capture probability $\left(P_{\mathrm{c}}\right)=0.8$, and capture time (for pursuit and handling after detection,

$$
\left.C_{\mathrm{ph}}\right)=1.2 \mathrm{~s}
$$

\section{Uncertainty analysis}

Because model algorithms for CAAU and LEAU were quite similar, the relative importance of parameter effects in uncertainty analyses were also similar, so here I present results only for CAAU. When selected
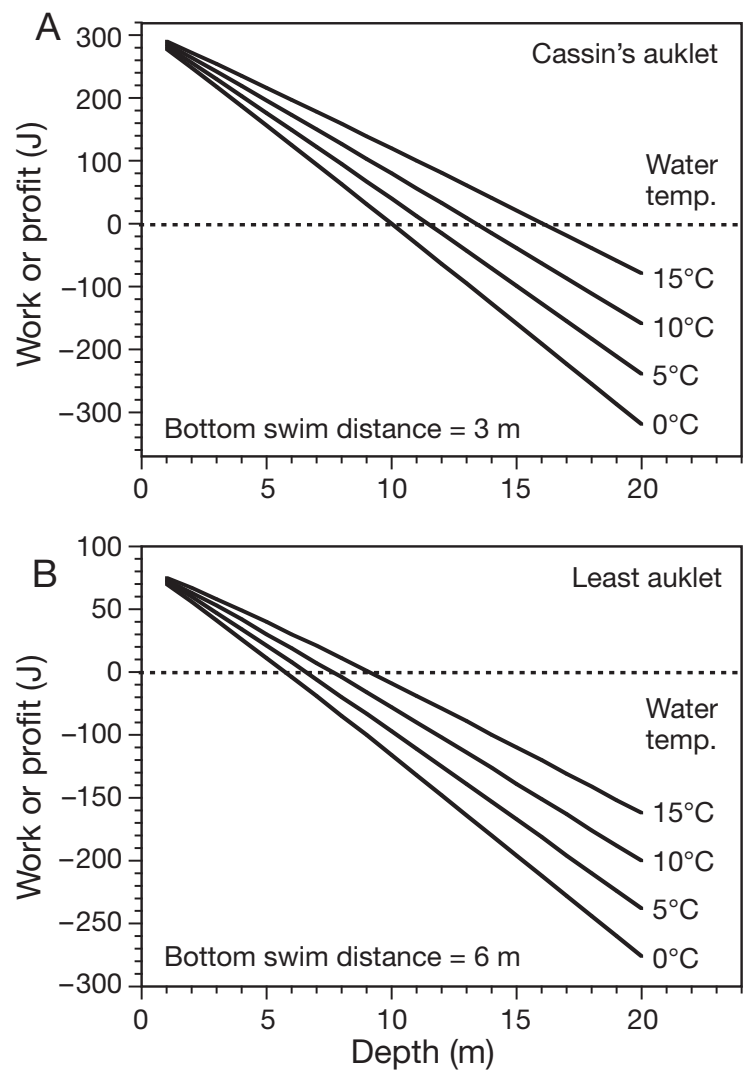

Fig. 13. Ptychoramphus aleuticus and Aethia pusilla. Model estimates of total dive profit as a function of dive depth and water temperature for (A) Cassin's auklets (CAAU) and (B) least auklets (LEAU) feeding within patches of adult krill Thysanoessa spp. or copepods Neocalanus plumchrus or $N$. flemingeri, respectively, with homogeneous density $=$ 150 prey $\mathrm{m}^{-3}$. For CAAU, capture probability $P_{\mathrm{c}}=0.8$, capture time $C_{\mathrm{ph}}=1.6 \mathrm{~s}$, and bottom swim distance $=3 \mathrm{~m}$. For LEAU, $P_{\mathrm{c}}=0.8 \mathrm{~s}, C_{\mathrm{ph}}=1.2$, and bottom swim distance $=6 \mathrm{~m}$

parameters were all varied over their possible ranges at the same time, the variables that most affected profit per dive for CAAU were bottom swim distance, aerobic efficiency for diving, and capture time for pursuit and handling after a prey item is detected (RPSS of 11 to $38 \%$, partial $\mathrm{r}^{2}$ of 0.14 to 0.30 , Table 2 ). The angle of passive ascent, which could be modulated by an initial propulsive stroke and subsequent position of the wings, affects the period over which RMR at the prevailing water temperature acts during ascent; this factor explained $6 \%$ of variation in profit per dive. Water temperature also acted mainly by varying the cost of RMR during passive ascent. Temperature effects on costs of descent and bottom foraging would be considered through changes in aerobic efficiency (Lovvorn 2007), which was also varied in this analysis.

Energy per krill prey, which can vary seasonally, had similar influence on both the variation in model predictions (RPSS $=6.24 \%$ ) and the fraction of total variance 
Table 2. Ptychoramphus aleuticus. Relative partial sums of squares (RPSS) and partial coefficients of determination (partial $\mathrm{r}^{2}$ ) from uncertainty analyses of the foraging model for Cassin's auklet $(0.17 \mathrm{~kg})$, with profit per dive $(\mathrm{J})$ as the dependent variable $(n=300$ simulated dives $) . \eta=$ mechanical power output/aerobic power input

\begin{tabular}{|lcc|}
\hline Parameter & RPSS $(\%)$ & Partial $\mathrm{r}^{2}$ \\
\hline Bottom swim distance $(\mathrm{m})$ & 37.79 & 0.30 \\
Aerobic efficiency for diving, $\eta$ & 23.04 & 0.25 \\
Capture time for pursuit and handling & 11.23 & 0.14 \\
$\quad$ after detection (s per prey) & & \\
Ascent angle $\left({ }^{\circ}\right)$ & 7.91 & 0.06 \\
Energy per prey $(\mathrm{J})$ & 6.24 & 0.06 \\
Water temperature $\left({ }^{\circ} \mathrm{C}\right)$ & 5.69 & 0.04 \\
Capture probability & 5.13 & 0.05 \\
Bottom swim speed $\left(\mathrm{m} \mathrm{s}^{-1}\right)$ & 2.32 & 0.02 \\
Prey density within a patch $\left(\mathrm{no.}^{-3}\right)$ & 0.65 & 0.01 \\
\hline
\end{tabular}

in profitability that was explained (partial $\left.r^{2}=0.06\right)$. By the visual foraging model used, the probability of capturing a prey once detected $\left(P_{\mathrm{c}}\right)$ was less than half as important to profit per dive as was capture time detection $\left(C_{\mathrm{ph}}\right)$. Varying bottom swim speed was a far less effective means of increasing time spent in a patch (and resulting total intake) than was varying the swim distance traveled within the patch. Varying prey density within a patch from 10 to $200 \mathrm{krill} \mathrm{m}^{-3}$ had little effect on profitability, mainly because intake rate did not change much above $50 \mathrm{krill} \mathrm{m}^{-3}$ (Fig. 9). Note that if variation in the uncertainty analysis had been restricted only to 5 to $50 \mathrm{krill} \mathrm{m}^{-3}$, prey density would have appeared more important, emphasizing that the range of variation used for a given variable can strongly affect inference from uncertainty analyses.

\section{DISCUSSION}

Few direct measurements are available on which to base a model of the underwater foraging energetics of Cassin's auklet (CAAU, 170 g) or least auklet (LEAU, $\sim 80 \mathrm{~g}$ ). Over the range of body mass within the family Alcidae (roughly 70 to $1250 \mathrm{~g}$ ), variables such as body surface area, swim speed during descent, and RMR in air at thermoneutral temperatures appear to scale almost linearly with body mass (Figs. 2,4A,6). These patterns suggest that as a first approximation, physiological or biomechanical measurements on larger alcids can be extrapolated to small auklets. However, differences in behavior, often resulting from different strategies of foraging for different prey taxa, can cause large variations that may confound body mass scaling (as for swim speed during ascent, Fig. 4B). Such behavioral variations may render body size alone a poor pre- dictor of the dispersion of different auklet species relative to the depth or patch structure of prey (cf. Haney 1991; Hunt et al. 1993, 1998; Mori 2002). Nevertheless, if models of intake rate that are specific to particular prey taxa are linked with models of foraging cost, better prediction of situations where different auklet species can forage profitably should be possible. Analyses in this paper indicate several areas where further research is most likely to improve such models.

\section{Thermoregulation and aerobic efficiency}

The model presented here is sensitive to variations in aerobic efficiency $(\eta=$ mechanical power output $\div$ aerobic power input, Table 2), which is used to convert mechanical estimates of dive costs into chemical substrates (food energy) needed for locomotion. Values of $\eta$ depend strongly on the accuracy of the mechanical model (i.e. $\eta$ is specific to a given model), and subsume thermoregulation costs (Lovvorn 2007). Depending on body size, water temperature, and exercise level, heat generated by exercising muscles may be less than heat lost, or may completely replace heat lost so that no shivering thermogenesis is needed. Shivering generally does not occur in actively exercising muscles; thus, maintenance of high core temperature throughout dives in TBMU (Niizuma et al. 2007) suggests that heat from exercising muscles replaces most heat lost to water. Body surface area and RMR in air at thermoneutrality scale almost linearly over the body mass range from LEAU to TBMU (Figs. 2 \& 6), so aerobic efficiency and thermoregulation costs it subsumes may also scale nearly linearly over this 18 -fold mass range (70 to $1250 \mathrm{~g})$.

However, $\eta$ may decrease rather abruptly with decreasing water temperature when heat loss exceeds a threshold beyond which exercise heat no longer replaces heat loss. As the approach used here to model dive costs depends strongly on estimates of aerobic efficiency, direct measurements of energy costs over a range of work rates and water temperatures in species of different sizes are needed to refine the predictive model. A similar threshold or nonlinearity may apply to RMR at different temperatures in water, despite apparent linearity of RMR in air at thermoneutral temperatures (Fig. 6). Heat loss to water is far greater than to air, and may induce sharp increases in metabolism for smaller animals at low temperatures. Water temperature may have important effects on the range of dive depths at which auklets of different sizes can forage profitably (Fig. 13), but data on which to base such estimates are currently inadequate. Cost measurements are needed for varying combinations of work rates, temperatures, and body sizes. 


\section{Model of intake rates}

The model of underwater visual foraging used in this paper (Lovvorn et al. 2001a) follows a prevalent approach for such models developed for fish (Aksnes \& Giske 1993), but is untested for birds. In essence, the model uses a Type II functional response, where intake rate increases with prey density up to an asymptote determined by handling time (Lovvorn \& Gillingham 1996). Because of limitation by pursuit and handling time $\left(C_{\mathrm{ph}}\right)$, intake rates of krill reached asymptotes at not much above $50 \mathrm{~m}^{-3}$ (Fig. 9). This density of adult krill within patches is much higher than densities $<10$ and often $<1 \mathrm{krill} \mathrm{m}^{-3}$ measured by towing nets that integrate densities over hundreds to thousands of meters (Simard \& Mackas 1989, Coyle \& Pinchuk 2002, Marinovic et al. 2002). Such extended tows may include no krill patches of high density, or else multiple patches ranging from a few meters to hundreds of meters across (O'Brien 1988, Tarling et al. 2009). Functional responses (Fig. 9) indicate that auklets benefit from finding krill patches with densities well above the average over larger scales. However, according to this model formulation, the very high densities of tens of thousands per $\mathrm{m}^{3}$ that can be reached in daytime surface swarms of krill (Hanamura et al. 1984, O'Brien 1988) would not improve within-patch intake rates for auklets over those achieved in patches with far lower density.

This inference has important implications for the amount of aerial or underwater searching needed to find prey patches that maximize intake rate (Wilson et al. 1996, Fauchald 1999, Veit 1999). Based on modeled intake rate within patches, one would expect the distributions of feeding CAAU to reflect variations in krill density below $50 \mathrm{~m}^{-3}$, but to be insensitive to variations above that threshold. However, very dense krill aggregations may be easier to find because the swarms themselves are more visible or predictable (Coyle et al. 1992), or because a number of other predators from seabirds to whales may gather at such swarms and thereby increase their visibility (Haney et al. 1992, Grunbaum \& Veit 2003). Such effects might confound the expected association of auklets with krill patches of different density based on maximum intake rate within a patch. The cost of searching for patches, which is not considered in this analysis, might also lead auklets to stay in patches that do not maximize intake rate if their energy needs are already being met at the current patch density, or if recent experience suggests that the probability of finding better patches is low.

Large copepods that comprise the main prey of LEAU can achieve much higher mean densities than those of krill in net tows that integrate densities over long horizontal distances (tens of copepods per $\mathrm{m}^{3}$, Coyle 1998). Copepods can also occur in very dense swarms (Ueda et al. 1983). However, the functional responses for LEAU (Fig. 10) again suggest limitation of intake rate by handling time at relatively low prey densities. For short-tailed shearwaters Puffinus tenuirostris, this limit on prey intake by bite-feeding may be avoided by filter-feeding, as simulated by Lovvorn et al. (2001a). However, the anatomical features thought to make filter-feeding possible in these shearwaters - long overlapping papillae on the palate and tongue, and openings near the rear of the bill for exit of water (Morgan \& Ritz 1982) - are lacking in the auklet species examined (DOVE were not included), with only a slight tendency toward those features in CAAU (Lovvorn et al. 2001a). Consequently, this paper only considers bite-feeding for LEAU and CAAU. Because of the very high intake rates of zooplankton required to meet energy requirements, Harding et al. (2009) also suggested the need for filter-feeding in DOVE. Direct measurements of intake rates by auklets feeding on krill and other zooplankton underwater are needed to clarify this issue, which is quite important to modeling trophic relations.

Once a suitable patch is found, the model predicts that the capture time $\left(C_{\mathrm{ph}}\right)$ is over twice as important as the capture probability $\left(P_{\mathrm{c}}\right)$ in determining profit per dive (Table 2). Thus, once a prey item is detected, increasing pursuit and handling speed at the expense of some decline in success rate appears to be a superior strategy. Because intake rate is limited at relatively low prey density (Figs. 9 \& 10), the only way to increase profit per dive above that threshold is to stay in a patch longer by swimming farther or slower. Over the ranges of values examined, increasing swim distance within a patch was a far more effective means of increasing total intake than was slowing down (Table 2). It is likely that effects of swim speed on locomotor efficiency, which were not considered here, would further restrict the range of variation in swim speed (Lovvorn et al. 2004); such limits would make increasing swim distance an even better alternative for extending time within patches.

The diets of different auklet species vary from copepods to larval fish to small jellyfish (Hunt et al. 1993, Adams et al. 2004a). Because of associated variations in prey size, energy content, escape responses, and swarming behavior (Hunt et al. 1998), we cannot yet generalize about energy intake rates during foraging bouts. Simple body mass scaling over the size range of small alcids is probably not valid ecologically for such variable foraging conditions (cf. Richman \& Lovvorn 2009). The visual foraging algorithm used in this paper is quite sensitive to capture time and capture probability (Figs. $9 \& 10$, Table 2); either factor can limit intake rates at prey densities that are orders of magnitude lower than can occur in swarms. The validity of this model formulation, and parameter values for different prey types and bird body sizes, need to be evaluated empirically. 


\section{Light effects and diel vertical migration}

Once a prey patch is located, changes in light conditions with depth had negligible effects on modeled intake rates over the depths typically used by these auklets $(<20$ m, Figs. $7 \& 9$ C). Prey intake was instead strongly limited by pursuit and handling time $\left(C_{\mathrm{ph}}\right)$, thus, even if more light allows the birds to see more prey, they cannot handle prey at a faster rate than is already detected at lower light levels (note that searching for patches was not considered in this paper). Experiments with captive little penguins likewise indicated that feeding on fish was not impaired by decreasing illumination until very low light levels were reached (Cannell \& Cullen 1998, $<0.1 \mu \mathrm{mol} \mathrm{m}^{-2} \mathrm{~s}^{-1}$, cf. Fig. 7A). However, dive depth had strong impacts on the foraging profitability of auklets by changing the costs of diving (Figs. 11 \& 12). Thus, light can have important indirect effects on profitability by controlling diel vertical migration that alters the depth of prey (Youngbluth 1976, Falk-Petersen et al. 2008).

It is difficult to compare such effects for small auklets diving mostly to depths $<20 \mathrm{~m}$ in highly productive (turbid) waters to patterns for much larger endotherms diving up to hundreds of meters in very clear Antarctic waters. For fur seals and penguins feeding on vertically migrating prey, interpretations vary on the relative importance to foraging profitability of light conditions for capturing prey versus costs of diving to different depths. During austral winter, Antarctic fur seals Arctocephalus gazella foraged only at night when krill moved up to the surface (Fraser et al. 1989), suggesting that dive depth was more important than light levels. For king penguins Aptenodytes patagonicus during austral summer, about $2 / 3$ of all dives were to depths $<20 \mathrm{~m}$ at night when their main prey of myctophid fish had migrated near the surface (Kooyman et al. 1992); however, $1 / 3$ of all dives were to depths of 100 to $300 \mathrm{~m}$ during the day with much higher dive costs that should decrease profitability. To explain why these penguins would make such deep dives during the day, the authors proposed either that total intake at night was inadequate to meet daily needs, that prey during deep daytime dives had higher energy content, or that prey were harder to capture at night despite being more vertically compressed. By using loggers to record ingestion events during austral summer, Wilson et al. (1993) showed that although king penguins and Adélie penguins Pygoscelis adeliae made many dives to shallow depths at night, catch per unit effort (CPUE) was lower at night and the birds obtained most of their prey by deeper dives during the day. Assuming that the prey of king penguins (mytophids) exhibited full vertical migration, and the prey of Adélie penguins (Antarctic krill Euphausia superba) underwent partial vertical migration, it was concluded that light levels that facilitated prey capture during the day were more important than reduced dive costs at night.

When CPUE of emperor penguins Aptenodytes forsteri was inferred from rapid fluctuations in depth during dives, in winter the birds dove only during the day with high CPUE when their krill prey remained close to the seabed and did not vertically migrate (Zimmer et al. 2008). In the spring, these penguins dove throughout the day, but achieved highest CPUE when light conditions were lowest at night; this pattern was attributed to resumption of diel vertical migration by both krill and nototheniid fish. This inference of higher intake rates for emperor penguins during shallow nighttime dives contrasts with the pattern for king penguins reported by Wilson et al. (1993) (see preceding paragraph). However, more frequent vertical fluctuations of depth during nighttime dives might actually indicate that greater effort was mandated by low success rates. During the summer, Bost et al. (2002) found that king penguins made only shallow dives at night but mostly deep dives during the day, and that light levels at those deep depths during the day were higher than light levels at the shallow depths of dives at night. Although intake rates were not measured or estimated, 30-min trawls at depths of 50,150,250, and $300 \mathrm{~m}$ indicated that the main prey taxa brought back to chicks were rare in the penguin's shallow nighttime diving range. These authors concluded that ambient light levels were more critical to foraging profitability than diel vertical migration of prey to shallow depths.

However, a potentially important aspect of diel vertical migration that these studies have not considered is change in horizontal dispersion of prey with change in depth. It is believed that vertically migrating zooplankton often disperse horizontally as they become more vertically compacted near the surface (Smith et al. 1989, Demer \& Hewitt 1995, Tarling et al. 1998). The extent to which this behavior results in less distinct patches with lower density near the surface, with increased costs of searching to locate high enough prey concentrations, is unknown. Although conditions during various studies will differ, it appears that king penguins generally make many shallow dives at night with low success rates, compared to fewer, deeper dives during the day with higher success rates. Trawls at depths of 50 and $100 \mathrm{~m}$ might miss dispersed layers of certain taxa that are vertically compacted near the surface (Sameoto 1983), and lack of the prey taxa brought to chicks in those trawls does not exclude the possibility that adults feed themselves on different prey captured during the many dives to shallow depths (cf. Bost et al. 2002). As vertically migrating zooplankton often become more clumped as they descend (Sprong \& Schalk 1992), increased prey density within 
larger, more distinct patches might help explain higher intake rates during deeper dives even with lower light levels. In a controlled study, cormorants detected prey only at close range, with capture by brief short-distance pursuit or rapid neck extensions (White et al. 2007). Such a strategy where intake rate is more limited by capture time after detection than by detection distance is consistent with the model used here, and may reduce the direct importance of ambient light levels on capture rates when prey are concentrated.

Hydroacoustic transducers have a near-field detection limit of 3 to $5 \mathrm{~m}$; because such instruments are typically pointed downward when mounted on ship hulls or towed underwater, very little is known about the patch structure of vertically migrating prey within $10 \mathrm{~m}$ of the water surface. It is possible that vertical compression of migrating krill layers near the water surface raises krill densities to as high as those in surface swarms (Sameoto 1983). However, the extent to which horizontal aggregations so apparent at depth are maintained in more vertically compressed layers near the surface is poorly known (cf. O'Brien 1988, Demer \& Hewitt 1995). Towing acoustic transducers pointed sideways or upward (Hewitt \& Demer 1996, Probst et al. 2009), towing video cameras (Veit et al. 2008) with some type of lighting for night use, or towing multiple closing nets tripped at short distance intervals near the surface may provide important information on krill dispersion. Measurements of the patch structure of vertically migrating krill and copepods near the water surface at night are needed as a basis for foraging experiments and modeling for small auklets.

Finally, this paper has explored mechanisms that determine whether a small-scale patch of zooplankton prey will allow energy intake to exceed the cost of individual dives. Profitability in this case has not included the costs of searching for the patch, or the overhead cost of other activities throughout the diel period (Lovvorn et al. 2009). Although flights of Cassin's auklets to general foraging locations have been documented by radiotelemetry (Adams et al. 2004b), aerial or underwater search patterns within such areas for small-scale prey patches are unknown (cf. Fauchald 1999). As loggers are increasingly miniaturized, data from the larger of the small auklets should provide critical insights for more comprehensive models.

Acknowledgements. Funding was provided by the US Geological Survey; the Oiled Wildlife Care Network of the State of California; and a Sabbatical Fellowship to JRL from the National Center for Ecological Analysis and Synthesis, a center funded by the National Science Foundation (DEB0553768), the University of California, Santa Barbara, and the State of California. I appreciate informative discussions and field opportunities provided by J. Adams, D. A. Croll, B. B. Marinovic, K. M. Newton, and J. Y. Takekawa. R. C. Reeves helped with $\mathrm{C}++$ programming.

\section{LITERATURE CITED}

Abraham CL, Sydeman WJ (2006) Prey-switching by Cassin's auklet Ptychoramphus aleuticus reveals seasonal climaterelated cycles of Euphausia pacifica and Thysanoessa spinifera. Mar Ecol Prog Ser 313:271-283

Adams J, Takekawa JY, Carter HR (2004a) Stable foraging areas and variable chick diet in Cassin's auklets (Ptychoramphus aleuticus) off southern California. Can J Zool 82: 1578-1595

Adams J, Takekawa JY, Carter HR (2004b) Foraging distance and home range of Cassin's auklets nesting at two colonies in the California Channel Islands. Condor 106: 618-637

Aksnes DL, Giske J (1993) A theoretical model of aquatic visual feeding. Ecol Modell 67:233-250

Bost CA, Zorn T, Le Maho Y, Duhamel G (2002) Feeding of diving predators and diel vertical migration of prey: king penguins' diet versus trawl sampling at Kerguelen Islands. Mar Ecol Prog Ser 227:51-61

Burger AE, Powell DW (1990) Diving depths and diet of Cassin's auklet at Reef Island, British Columbia. Can J Zool 68:1572-1577

Butler PJ, Green JA, Boyd IL, Speakman JR (2004) Measuring metabolic rate in the field: the pros and cons of the doubly labeled water and heart rate methods. Funct Ecol 18: 168-183

Caccamise DF, Hedin RS (1985) An aerodynamic basis for selecting transmitter loads in birds. Wilson Bull 97:306-318

Campbell RW, Boutillier P, Dower JF (2004) Ecophysiology of overwintering in the copepod Neocalanus plumchrus: changes in lipid and protein contents over a seasonal cycle. Mar Ecol Prog Ser 280:211-226

Cannell BA, Cullen JM (1998) The foraging behaviour of little penguins Eudyptula minor at different light levels. Ibis 140:467-471

Coyle KO (1998) Neocalanus scattering layers near the western Aleutian Islands. J Plankton Res 20:1189-1202

> Coyle KO, Pinchuk AI (2002) The abundance and distribution of euphausiids and zero-age pollock on the inner shelf of the southeast Bering Sea near the Inner Front in 1997-1999. Deep-Sea Res II 49:6009-6030

Coyle KO, Hunt GL, Decker MB, Weingartner TJ (1992) Murre foraging, epibenthic sound scattering and tidal advection over a shoal near St. George Island, Bering Sea. Mar Ecol Prog Ser 83:1-14

> Croll DA, McLaren E (1993) Diving metabolism and thermoregulation in common and thick-billed murres. J Comp Physiol B 163:160-166

Culik B, Wilson RP (1991) Swimming energetics and performance of instrumented Adélie penguins (Pygoscelis adeliae). J Exp Biol 158:355-368

> Demer DA, Hewitt RP (1995) Bias in acoustic biomass estimates of Euphausia superba due to diel vertical migration. Deep-Sea Res I 42:455-475

Denlinger L (2006) Alaska seabird information series. US Fish $\&$ Wildl Serv, Anchorage, AK

Durell SEA Le V dit, Stillman RA, Caldow RWG, McGrorty S, West AD, Humphreys J (2006) Modelling the effect of environmental change on shorebirds: a case study on Poole Harbour, UK. Biol Conserv 131:459-473

> Enstipp MR, Grémillet D, Jones DR (2006) The effects of depth, temperature and food ingestion on the foraging energetics of a diving endotherm, the double-crested cormorant (Phalacrocorax auritus). J Exp Biol 209:845-859

> Enstipp MR, Grémillet D, Jones DR (2007) Investigating the functional link between prey abundance and seabird 
predatory performance. Mar Ecol Prog Ser 331:267-279

Falk-Petersen S, Leu E, Berge J, Kwasniewski S and others (2008) Vertical migration in high Arctic waters during autumn 2004. Deep-Sea Res II 55:2275-2284

Fauchald P (1999) Foraging in a hierarchical patch system. Am Nat 153:603-613

Fiedler PC, Reilly SB, Hewitt RP, Demer D and others (1998) Blue whale habitat and prey in the California Channel Islands. Deep-Sea Res II 45:1781-1801

Fraser WR, Pitman RL, Ainley DG (1989) Seabird and fur seal responses to vertically migrating winter krill swarms in Antarctica. Polar Biol 10:37-41

Gabrielsen GW, Mehlum F, Karlsen HE (1988) Thermoregulation in four species of Arctic seabirds. J Comp Physiol B 157:703-708

Gabrielsen GW, Taylor JRE, Konarzewski M, Mehlum F (1991) Field and laboratory metabolism and thermoregulation in dovekies (Alle alle). Auk 108:71-78

Gall AE, Roby DD, Irons DB, Rose I (2006) Differential response in chick survival to diet in least and crested auklets. Mar Ecol Prog Ser 308:279-291

Gaston AJ, Jones IL (1998) The auks, Alcidae. Oxford University Press, UK

Grunbaum D, Veit RR (2003) Black-browed albatrosses foraging on Antarctic krill: Density-dependence through local enhancement? Ecology 84:3265-3275

Halsey LG, Shepard ELC, Quintana F, Gomez Laich A, Green JA, Wilson RP (2009) The relationship between oxygen consumption and body acceleration in a range of species. Comp Biochem Physiol A 152:197-202

Hamer KC, Humphreys EM, Magalhães MC, Garthe S and others (2009) Fine-scale foraging behaviour of a mediumranging marine predator. J Anim Ecol 78:880-889

Hanamura Y, Endo Y, Taniguchi A (1984) Underwater observations on the surface swarm of a euphausiid, Euphausia pacifica in Sendai Bay, northeastern Japan. La Mer (Paris) 22:63-68

Haney JC (1991) Influence of pycnocline topography and water-column structure on marine distributions of alcids (Aves: Alcidae) in Anadyr Strait, northern Bering Sea, Alaska. Mar Biol 110:419-435

Haney JC, Fristrup KM, Lee DS (1992) Geometry of visual recruitment by seabirds to ephemeral foraging flocks. Ornis Scand 23:49-62

Harding AMH, Egevang C, Walkusz W, Merkel F, Blanc S, Grémillet D (2009) Estimating prey capture rates of a planktivorous seabird, the little auk (Alle alle), using diet, diving behaviour, and energy consumption. Polar Biol 32:785-796

Hewitt RP, Demer DA (1996) Lateral target strength of Antarctic krill. ICES J Mar Sci 53:297-302

> Hunt GL, Harrison NM (1990) Foraging habitat and prey taken by least auklets at King Island, Alaska. Mar Ecol Prog Ser 65:141-150

Hunt GL, Harrison NM, Piatt JF (1993) Foraging ecology as related to the distribution of planktivorous auklets in the Bering Sea. In: Vermeer K, Briggs KT, Morgan KH, SiegelCausey D (eds) The status, ecology, and conservation of marine birds of the North Pacific. Can Wildl Serv Spec Publ, Ottawa

Hunt GL, Russell RW, Coyle KO, Weingartner T (1998) Comparative foraging ecology of planktivorous auklets in relation to ocean physics and prey availability. Mar Ecol Prog Ser 167:241-259

Ikeda T (1972) Chemical composition and nutrition of zooplankton in the Bering Sea. In: Takenouti AY (ed) Biological oceanography of the north Pacific Ocean. Idemitsu
Shoton, Tokyo

Jackson S (1986) Assimilation efficiencies of white-chinned petrels (Procellaria aequinoctalis) fed different prey. Comp Biochem Physiol A 85:301-303

Karnovsky NJ, Hunt GL (2002) Estimation of carbon flux to dovekies (Alle alle) in the North Water. Deep-Sea Res II 49:5117-5130

Kaseloo PA, Lovvorn JR (2005) Effects of surface activity patterns and dive depth on thermal substitution in fasted and fed lesser scaup ducks. Can J Zool 83:301-311

Kaseloo PA, Lovvorn JR (2006) Substitution of heat from exercise and digestion by ducks diving for mussels at varying depths and temperatures. J Comp Physiol B 176:265-275

> Kato A, Watanuki Y, Naito Y (2003) Foraging behaviour of chick-rearing rhinoceros auklets Cerorhinca monocerata at Teuri Island, Japan, determined by acceleration-depth recording micro data loggers. J Avian Biol 34:282-287

> Kirkwood R, Robertson G (1997) The energy assimilation efficiency of emperor penguins, Aptenodytes forsteri, fed a diet of Antarctic krill, Euphausia superba. Physiol Zool 70:27-32

Kochin NE, Kibel IA, Roze NV (1964) Theoretical hydromechanics. Interscience Publishers, New York

Kooyman GL, Cherel Y, Le Maho Y, Croxall JP, Thorson PH, Ridoux V, Kooyman CA (1992) Diving behavior and energetics during foraging cycles in king penguins. Ecol Monogr 62:143-163

Lasiewski RC, Calder WA (1971) A preliminary allometric analysis of respiratory variables in resting birds. Respir Physiol 11:152-166

Lovvorn JR (2007) Thermal substitution and aerobic efficiency: measuring and predicting effects of heat balance on endotherm diving energetics. Philos Trans R Soc Lond, B 362:2079-2093

Lovvorn JR, Gillingham MP (1996) Food dispersion and foraging energetics: a mechanistic synthesis for field studies of avian benthivores. Ecology 77:435-451

Lovvorn JR, Jones DR (1991) Effects of body size, body fat, and change in pressure with depth on buoyancy and costs of diving in ducks (Aythya spp.). Can J Zool 69:2879-2887

Lovvorn JR, Jones DR, Blake RW (1991) Mechanics of underwater locomotion in diving ducks: drag, buoyancy and acceleration in a size gradient of species. J Exp Biol 159: 89-108

Lovvorn JR, Croll DA, Liggins GA (1999) Mechanical versus physiological determinants of swimming speeds in diving Brünnich's guillemots. J Exp Biol 202:1741-1752

Lovvorn JR, Baduini CL, Hunt GL (2001a) Modeling underwater visual and filter feeding by planktivorous shearwaters in unusual sea conditions. Ecology 82:2342-2356

Lovvorn JR, Liggins GA, Borstad MH, Calisal SM, Mikkelsen $\mathrm{J}$ (2001b) Hydrodynamic drag of diving birds: effects of body size, body shape and feathers at steady speeds. J Exp Biol 204:1547-1557

Lovvorn JR, Watanuki Y, Kato A, Naito Y, Liggins GA (2004) Stroke patterns and regulation of swim speed and energy cost in free-ranging Brünnich's guillemots. J Exp Biol 207: $4679-4695$

> Lovvorn JR, Grebmeier JM, Cooper LW, Bump JK, Richman SE (2009) Modeling marine protected areas for threatened eiders in a climatically changing Bering Sea. Ecol Appl 19: 1596-1613

Marinovic BB, Croll DA, Gong N, Benson SR, Chavez FP (2002) Effects of the 1997-1999 El Niño and La Niña events on zooplankton abundance and euphausiid community composition within the Monterey Bay coastal upwelling system. Prog Oceanogr 54:265-277 
Morgan WL, Ritz DA (1982) Comparison of the feeding apparatus in the muttonbird, Puffinus tenuirostris (Temminck) and the fairy prion, Pachyptila turtur (Kuhl) in relation to the capture of the krill, Nyctiphanes australis Sars. J Exp Mar Biol Ecol 59:61-75

Mori Y (1998) The optimal patch use in divers: optimal time budget and the number of dive cycles during the bout. J Theor Biol 190:187-199

Mori Y (2002) Optimal diving behavior for foraging in relation to body size. J Evol Biol 15:269-276

Niizuma Y, Gabrielsen GW, Sato K, Watanuki Y, Naito Y (2007) Brünnich's guillemots (Uria lomvia) maintain high temperature in the body core during dives. Comp Biochem Physiol A 147:438-444

Nishiyama T (1974) Energy requirement of Bristol Bay sockeye salmon in the central Bering Sea and Bristol Bay. In: Hood DW, Kelley EJ (eds) Oceanography of the Bering Sea with emphasis on renewable resources. Institute of Marine Science, University of Alaska, Fairbanks

O'Brien DP (1988) Surface schooling behavior of the coastal krill Nyctiphanes australis (Crustacea: Euphausiacea) off Tasmania, Australia. Mar Ecol Prog Ser 42:219-233

> Paredes R, Jones IL, Boness DJ (2005) Reduced parental care, compensatory behaviour and reproductive costs of thickbilled murres equipped with data loggers. Anim Behav 69:197-208

Probst WN, Thomas G, Eckmann R (2009) Hydroacoustic observations of surface shoaling behavior of young-of-theyear perch Perca fluviatilis (Linnaeus, 1758) with a towed upward-facing transducer. Fish Res 96:133-138

Richman SE, Lovvorn JR (2008) Costs of diving by wing and foot propulsion in a sea duck, the white-winged scoter. J Comp Physiol B 178:321-332

Richman SE, Lovvorn JR (2009) Predator size, prey size, and threshold food densities of diving ducks: Does a common prey base support fewer larger animals? J Anim Ecol 78:1033-1042

Roby DD (1991) Diet and postnatal energetics in convergent taxa of plankton-feeding seabirds. Auk 108:131-146

Roby DD, Ricklefs RE (1986) Energy expenditure in adult least auklets and diving petrels during the chick-rearing period. Physiol Zool 59:661-678

Roby DD, Place AR, Ricklefs RE (1986) Assimilation and deposition of wax esters in planktivorous seabirds. J Exp Zool 238:29-41

Ropert-Coudert Y, Knott N, Chiaradia A, Kato A (2007) How do different logger sizes and attachment positions affect the diving behaviour of little penguins? Deep-Sea Res II 54:415-423

Sameoto DD (1983) Euphausiid distribution in acoustic scattering layers and its significance to surface swarms. J Plankton Res 5:129-143

Schneider D, Hunt GL (1982) Carbon flux to seabirds in waters with different mixing regimes in the southeastern Bering Sea. Mar Biol 67:337-344

Simard Y, Mackas DL (1989) Mesoscale aggregations of euphausiid sound scattering layers on the continental shelf of Vancouver Island. Can J Fish Aquat Sci 46: 1238-1249

Submitted: August 5, 2009; Accepted: November 12, 2009
Smith PE, Ohman MD, Eber LE (1989) Analysis of the patterns of distribution of zooplankton aggregations from an acoustic Doppler current profiler. CalCOFI Rep: 30:88-103

Sprong I, Schalk PH (1992) Acoustic observations on krill spring-summer migration and patchiness in the northern Weddell Sea. Polar Biol 12:261-268

Tarling GA, Matthews JBL, Saborowski R, Buchholz F (1998) Vertical migratory behavior of the euphausiid, Meganyctiphanes norvegica, and its dispersion in the Kattegat Channel. Hydrobiologia 375-376:331-341

Tarling GA, Klevjer T, Fielding S, Watkins J and others (2009) Variability and predictability of Antarctic krill swarm structure. Deep-Sea Res I 56:1994-2012

- Thompson D, Fedak MA (2001) How long should a dive last? A simple model of foraging decisions by breath-hold divers in a patchy environment. Anim Behav 61:287-296

Tremblay Y, Cherel Y, Oremus M, Tveraa T, Chastel O (2003) Unconventional ventral attachment of time-depth recorders as a new method for investigating time budget and diving behavior of seabirds. J Exp Biol 206:1929-1940

> Ueda H, Kuwahara A, Tanaka M, Azeta M (1983) Underwater observations on copepod swarms in temperate and subtropical waters. Mar Ecol Prog Ser 11:165-171

Veit RR (1999) Behavioural responses by foraging petrels to swarms of Antarctic krill Euphausia superba. Ardea 87: $41-50$

Veit RR, Santora JA, Owen H (2008) Using a video camcorder to quantify spatial association between seabirds and their prey. Mar Ornithol 36:147-153

- Vermeer K (1984) The diet and food consumption of nestling Cassin's auklets during summer, and a comparison with other plankton-feeding alcids. Murrelet 65:65-77

Watanuki Y, Wanless S, Harris M, Lovvorn JR, Miyazaki M, Tanaka H, Sato K (2006) Swim speeds and stroke patterns in wing-propelled divers: a comparison among alcids and a penguin. J Exp Biol 209:1217-1230

White CR, Day N, Butler PJ, Martin GR (2007) Vision and foraging in cormorants: More like herons than hawks? PLoS ONE 2:e639 doi: 10.1371/journal.pone.0000639

Wilson RP, Hustler K, Ryan PG, Burger AE, Noldeke EC (1992) Diving birds in cold water: Do Archimedes and Boyle determine energetic costs? Am Nat 140:179-200

Wilson RP, Puetz K, Bost CA, Culik BM, Bannasch R, Reins T, Adelung D (1993) Diel dive depth in penguins in relation to diel vertical migration of prey: Whose dinner by candlelight? Mar Ecol Prog Ser 94:101-104

Wilson RP, Culik BM, Peters G, Bannasch R (1996) Diving behavior of gentoo penguins, Pygoscelis papua; factors keeping dive profiles in shape. Mar Biol 126:153-162

Ydenberg RC, Clarke CW (1989) Aerobiosis and anaerobiosis during diving by western grebes: an optimal foraging approach. J Theor Biol 139:437-449

Youngbluth MJ (1976) Vertical distribution and diel migration of euphausiids in the central region of the California Current. Fish Bull 74:925-936

Zimmer I, Wilson RP, Beaulieu M, Ancel A, Plötz J (2008) Seeing the light: depth and time restrictions in the foraging capacity of emperor penguins at Pointe Géologie, Antarctica. Aquat Biol 3:217-226

Proofs received from author(s): March 10, 2010 